\title{
O gênero Phyllanthus L. (Phyllantheae - Euphorbiaceae Juss.) no bioma Caatinga do estado de Pernambuco - Brasil ${ }^{1}$
}

\author{
Marcos José da Silva ${ }^{2}$ \\ Margareth Ferreira de Sales ${ }^{3}$
}

\begin{abstract}
RESUMO
O estudo taxonômico de Phyllanthus L. no bioma Caatinga de Pernambuco foi realizado através da análise morfológica de materiais herborizados e de observações de campo. Constataramse 11 taxa: Phyllanthus acuminatus Vahl., P. amarus Schumach. \& Thonn., P. caroliniensis Walt. subsp. caroliniensis., P. claussenii Müll. Arg., P. jacobinensis Müll. Arg., P. klotzschianus Müll. Arg., P. minutulus Müll. Arg., P niruri L., P. heteradenius Müll. Arg., P. stipulatus (Raf.) Webster e $P$. tenellus Roxb. Os principais caracteres morfológicos utilizados para separação das espécies foram o hábito, o padrão de ramificação, a forma do disco glandular das flores de ambos os sexos, o número e união dos estames e a ornamentação das sementes. A maior parte das espécies apresenta distribuição nas subzonas do agreste e sertão em vegetação de Caatinga. Apenas P. acuminatus Vahl, P. minutulus Müll. Arg. e P. stipulatus (Raf.) Webster foram encontradas exclusivamente na subzona do Agreste, nas florestas Montanas.
\end{abstract}

Palavras chaves: Phyllanthus, Euphorbiaceae, Taxonomia, Caatinga, Pernambuco

\begin{abstract}
The taxonomic study of species in the genus Phyllanthus L. in the caatinga biome of the State of Pernambuco was carried out based on morphological analysis of fresh material or from specimen vouchers of the local herbaria. Eleven taxa were recorded: Phyllanthus acuminatus Vahl, P. amarus Schumach. \& Thonn., P. caroliniensis Walt. subsp. caroliniensis, P. claussenii Müll. Arg., P. heteradenius Müll. Arg., P. jacobinensis Müll. Arg., P. klotzschianus Müll. Arg., P. minutulus Müll. Arg., P niruri L., P. orbiculatus Rich., P. stipulatus (Raf.) Webster. and $P$. tenellus Roxb. The main morphological features used for delimitation of the species were habit, branching pattern, shape of the glandular disk on both male and female flowers, number and union of the stamens, type of dehiscence of anthers and seed coat. Most species present geographical distribution in steppe-savannah vegetation on different vegetational physiognomies (Agreste and Sertão). Only P. acuminatus Vahl., P. minutulus Müll. Arg. and P. stipulatus (Raf.) Webster occur exclusively in the upland forests within the Agreste Zone.
\end{abstract}

Key words: Phyllanthus, Euphorbiaceae, Taxonomy, Caatinga, Pernambuco's state.

\section{INTRODUÇÃO}

Phyllanthus L. compreende cerca de 800 espécies, alocadas em mais de 50 seções, com distribuição em diversos ambientes e tipos vegetacionais das regiões tropicais do mundo. Apresenta como importantes centros de diversidade de espécies as Américas (200 spp.), a África (100 spp.) e Madagascar (70 spp.) (Webster, 1970, 1994b). No Brasil, está representado por mais de 100 espécies, amplamente distribuídas em diferentes ambientes.

Este gênero posiciona-se na subfamília Phyllanthoideae, tribo Phyllantheae, subtribo Flueggeinae. É reconhecido por vários sistematas (Croizat, 1943; Webster, 1956, 1967, 1970, 1986; Hunter \& Bruhl, 1997a, 1997b e Rossignol et al., 1986) como sendo um dos maiores e mais complexos de Euphorbiaceae,

\footnotetext{
${ }^{1}$ Projeto financiado pelo $\mathrm{CNPq} / \mathrm{UFRPE}$

${ }^{2}$ Bolsista de Iniciação Científica - PIBIC/CNPq/UFRPE. phyllgradyanus@ig.com.br

${ }^{3}$ Professora do Departamento de Biologia - Universidade Federal Rural de Pernambuco. mfsales.2002@ig.com.br
} 
devido à ampla diversidade de caracteres vegetativos e florais.

A primeira referência a Phyllanthus é feita por Linnaeus (1737) no "Systema Naturae", embora este gênero só tenha sido estabelecido, posteriormente, por Linnaeus em 1753 no "Species Plantarum". Os primeiros trabalhos que trataram a taxonomia de Phyllanthus foram os de Grisebach (1858, 1860) e Baillon $(1858,1860)$, os quais forneceram descrições de novas espécies e seções. Posteriormente, Müeller (1866) no "Prodromus" de De candolle, propôs a primeira classificação infrangenérica, reconhecendo 44 seções, a qual foi utilizada como base para tratamentos posteriores como os de Bentham (1880), Robison (1909) e Pax \& Hoffmann (1986).

$\mathrm{O}$ conceito atual do gênero e os tratamentos mais recentes foram desenvolvidos por Webster (1956, 1957, 1958, 1967, 1970, 1986 e 2002) e complementados por Rossignol et al. (1986) e Hunter \& Bruhl (1997a, 1997b). Phyllanthus teve seu conhecimento ampliado com a elaboração de importantes floras nos continentes americano (Small, 1933; Standley, 1937, 1926; Lourteig \& O'Donell, 1942; Croizat, 1943, 1944; Standley \& Steyermark, 1949 Macbride, 1951; Adams, 1972; Hunziker, 1967; Webster \& Burch, 1967; Gillespie, 1993; Webster, 1986), africano (Radcliffe-Smith, 1883), asiático (Zoku, 1965; Airy Shaw, 1971) e australiano (Hunter \& Bruhl, 1997a, 1977b), as quais fornecem descrições de novas espécies, comentários sobre distribuição geográfica e afinidades entre espécies.

No Brasil poucos estudos taxonômicos foram elaborados sobre Phyllanthus. O mais significativo, pelo número de espécies tratadas (71), foi o de Müeller (1873) na "Flora brasiliensis", seguido de Santiago (1988) tratando Phyllanthus sect. Choretropsis, para o estado do Rio de Janeiro. Descrições e comentários sobre espécies ainda são encontrados em floras locais como as de Santa Catarina, por Smith et al., 1988 e Ulysséa \&
Amaral (1993, 1997), do Rio Grande do Sul, por Allem (1977), da Serra do Cipó (MG), por Cordeiro (1992), do Pico das Almas (BA), por Cordeiro (1995), do Parque Estadual Zoobotânico (PI), por Filho (2000) e da região de Xingó (AL e SE), por Silva \& Sales (inéd.).

$\mathrm{O}$ estudo objetivou reconhecer as espécies de Phyllanthus ocorrentes no bioma Caatinga de Pernambuco, através da análise de caracteres morfológicos vegetativos e reprodutivos, visando contribuir com o conhecimento do gênero e da flora de Pernambuco.

\section{MATERIAL E MÉTODOS}

Área de estudo - $\mathrm{O}$ estado de Pernambuco, situado entre as coordenadas $7^{\circ} 15^{\prime} 45^{\prime \prime} \mathrm{S}$ e $9^{\circ}$ $28^{\prime} 18^{\prime \prime} \mathrm{S}$ e $34^{\circ} 48^{\prime} 35^{\prime \prime} \mathrm{W}$ e $41^{\circ} 19^{\prime} 54^{\prime \prime} \mathrm{W}$, localiza-se no Nordeste brasileiro e possui uma área de 98. $307 \mathrm{~km}^{2}$ (Andrade-Lima, 1960). Divide-se em quatro zonas fitogeográficas: Litoral, Mata, das Caatingas e Savanas, as quais foram estabelecidas por Andrade-Lima (1960) fundamentado em dados edafoclimáticos e vegetacionais. Este autor ainda dividiu as zonas das Caatingas em duas subzonas: Agreste e Sertão, com base nos aspectos fisionômicos, índices pluviométricos e profundidade de solos. Para a subzona do Sertão o autor reconheceu ainda as regiões do Sertão Central, do Jatinã, do Araripe, do São Francisco e dos Chapadões Cretáceos. O clima de um modo geral é do tipo Bshw (Köeppen, 1948), as chuvas são irregulares com índices de precipitação anual variando de 252 a 1200mm (Sampaio, 1996).

A zona da Caatinga, a maior delas, ocupa uma área de 83. $560.95 \mathrm{Km}^{2}$, se estende de leste a oeste, perfazendo um total de $85 \%$ de todo o Estado. Nesta zona está assentado o bioma Caatinga. De acordo com Sales et al. (1998), neste bioma predomina a vegetação de Caatinga (caducifólia e espinhosa), entremeada por floresta Montana nos topos e encostas de serra, em altitudes superiores a $700 \mathrm{~m}$ e por uma vegetação arbustiva perenifólia sobre chapadas com altitudes entre 500 e $800 \mathrm{~m}$. 
O gênero Phyllanthus L. (Phyllantheae - Euphorbiaceae Juss.) no bioma Caatinga do estado de Pernambuco - Brasil

Estudo Taxonômico - Foram realizadas coletas mensais em vários municípios para obtenção de material botânico e observação das populações em campo. O material coletado, após processamento, foi depositado no herbário PEUFR da Universidade Federal Rural de Pernambuco. A identificação dos taxa fundamentou-se principalmente nas obras já mencionadas na introdução deste artigo. Para padronizar a terminologia das estruturas vegetativas e reprodutivas, utilizou-se Radford et al. (1974), para indumento, Lawrence (1951), Hickey (1973) para designar o padrão de venação e Brummitt \& Powell (1992) para grafia dos nomes dos autores.

\section{RESULTADOS E DISCUSSÃO}

Phyllanthus L., Sp. pl. 981. 1753.

Espécie Tipo: Phyllanthus niruri L.

Ervas, subarbustos, arbustos, raro árvores, monóicos ou mais raramente dióicos. Padrão de ramificação não filantóide, com ramos persistentes variadamente ramificados, ou filantóide, com ramos em geral decíduos, ortotrópicos e dispostos espiraladamente ao longo do ramo principal (caule), ou de suas ramificações, com aspecto pinatiforme (assemelhando-se a uma folha composta pinada) ou bipinatiforme (assemelhando-se a uma folha composta bipinada), modificados ou não em cladódios. Catafilos 3 , na base dos ramos com padrão filantóide. Folhas alternas, inteiras, pecioladas, estipuladas, aglandulares e em geral destituídas de indumento; venação broquidódroma. Inflorescências axilares, usualmente cimosas, címulas unissexuais e ou bissexuais, paucifloras, multifloras, agregadas ou não, às vezes reduzidas a flores solitárias. Flores monoclamídeas; cálice gamossépalo, lobos 4-6, imbricados. Flores estaminadas, pediceladas; disco extra-estaminal segmentado, mais raramente íntegro, segmentos de formas variadas, alternissépalos; estames (2) 3-5, livres, unidos ou parcialmente unidos pelos filetes em coluna, anteras livres ou aderidas no ápice da coluna, rimas horizontais a verticais. Flores pistiladas, pediceladas; disco em geral íntegro, anular, pateliforme a cupuliforme; ovário 3-carpelar; estiletes livres ou basalmente unidos, bífidos, raro inteiros, estigmas punctados ou captados; óvulos 2, em cada lóculo. Cápsula septicida e loculicida; cálice e estigma persistentes no fruto. Sementes em geral trígonas, por compressão dos óvulos nos lóculos do ovário, tegumento seco ou crustáceo, diversificadamente esculturado; endosperma carnoso, embrião estreito, reto ou ligeiramente curvo, cotilédones mais largos que a radícula.

\section{Aspectos morfológicos relevantes na identificação dos taxa encontrados}

As espécies registradas neste estudo podem ser identificadas principalmente através dos seguintes caracteres: padrão de ramificação, forma da lâmina foliar, tipo, sexo e disposição das inflorescências e das flores ao longo dos ramos, integridade e número de estames, deiscência das anteras, integridade e aspecto do disco glandular nas flores estaminadas e ornamentação da testa das sementes.

Padrão de ramificação - Um dos atributos mais utilizados por sistematas atuais (Webster, 1956, 1958, 1967, 1970, 1986; Rossignol et al., 1986 e Hunther \& Bhrul, 1997a) para separação dos grupos em Phyllanthus, é o padrão de ramificação, embora não tenha sido utilizado pelos botânicos clássicos (Müeller, 1866, 1873; Pax \& Hoffmman 1896; Baillon, 1860 e Robison, 1909).

Q taxa estudados mostraram-se ramificados nos seguintes padrões: filantóide e não filantóide. O primeiro padrão é encontrado em mais da metade das espécies do gênero, principalmente nos taxa herbáceas. Caracterizase por apresentar ramos ortotrópicos, em geral decíduos, dispostos espiraladamente ao longo do ramo principal (caule) ou de suas ramificações e catafilos, em número de três, no ponto de inserção de cada ramificação. No segundo padrão, os ramos são variadamente ramificados, persistentes, não ortotrópicos e os catafilos são ausentes. 
No padrão filantóide os ramos possuem aspecto pinatiforme (por apresentar folhas dispostas disticamente, assemelhando-se a uma folha composta pinada) ou bipinatiforme (por apresentar ramos secundários com disposição dística, nos quais as folhas são dispostas disticamente, conferindo aspecto de uma folha composta bipinada). Às vezes os ramos secundários e terciários podem ser modificados em cladódios. Ramificação filantóide com ramos pinatiformes é encontrada em Phyllanthus amarus, P. minutulus, $P$. niruri, $P$. stipulatus e $P$. tenellus, enquanto ramificação filantóide com ramos bipinatiformes ocorre em $P$. acuminatus e $P$. klotzschianus, sendo modificados em cladódios no segundo.

Ramificação não filantóide foi encontrada em Phyllanthus caroliniensis subsp. caroliniensis, $P$. claussenii, $P$. jacobinensis e $P$. heteradenius, sendo que no primeiro taxon os ramos, embora dispostos disticamente, têm quase o mesmo tamanho conferindo a planta um aspecto pinatiforme.

Lâmina foliar - As folhas em Phyllanthus são alternas, simples, inteiras, curtamente pecioladas a subsésseis, estipuladas, aglandulares e de margens em geral inteiras. Estão ausentes em P. klotzschianus. A lâmina é pouco variável em tamanho e forma. Variam de 2,6-5,1 x 1,4-2 mm em P. minutulus a 2,5-5 x 1,4-2,5 $\mathrm{cm}$ em $P$. acuminatus. Quanto à forma há um predomínio de lâminas oblongas, oblongo-obovais e oblongoelípticas, poucas são elípticas a ovais e apenas uma é orbicular como em P. claussenii. A consistência é, na maioria das espécies, membranácea e a venação é broquidodróma. $\mathrm{O}$ pecíolo é pouco variável, sendo comumente cilíndrico, nas espécies estudadas, com dimensões variando desde 0,3-0,4 $\mathrm{mm}$ em $P$. minutulus a 1,4-2 mm em P. acuminatus.

Inflorescências - As inflorescências em Phyllanthus variam de cincínios a fascículos, embora o tipo címula seja o mais comum em todo o gênero. É freqüente a ocorrência de címulas reduzidas a uma flor e de flores pistiladas solitárias (Webster, 1956). As címulas podem ser paucifloras ou multifloras, laxas ou congestas, unissexuais e ou bissexuais. Nos taxa estudados o tipo címula foi o predominante, sendo encontrado em todas as espécies. Címulas unissexuais estaminadas foram encontradas em Phyllanthus stipulatus, P.minutulus, $P$. niruri, $P$. heteradenius e P. klotzschianus, enquanto que as bissexuais ocorreram em $P$. acuminatus, $P$. amarus $P$. caroliniensis subsp. caroliniensis, $P$. claussenii e $P$. jacobinensis. Címulas bissexuais e unissexuais na mesma planta foram encontradas em $P$. tenellus, sendo as bissexuais constituídas por 1-2 flores estaminadas e 1-2 flores pistiladas, e as unissexuais formadas por apenas uma só flor pistilada, com o pedicelo visivelmente articulado de base pulviniforme.

As inflorescências apresentam sempre disposições axilares, que pode ser ao longo de todo o comprimento do ramo (na maioria das espécies) ou da base até a metade do seu comprimento como em Phyllanthus stipulatus, $P$. minutulus e $P$. niruri. As flores solitárias estão sempre nas terminações dos ramos como pode ser observado nas três espécies citadas anteriormente. Para Webster (1956) esta condição de distribuição floral das espécies acima é típica de um grande número de espécies herbáceas da seção Phyllanthus e parece evidenciar tendência ao dioicismo. Situação semelhante também foi observada em $P$. heteradenius que apresenta ramos exclusivamente unissexuais, estaminados ou pistilados, no mesmo indivíduo.

O arranjo distributivo das inflorescências nas plantas parece estar relacionado com o padrão de ramificação. Nas espécies que apresentam o padrão filantóide, as inflorescências estão dispostas exclusivamente na axila das folhas; já nas espécies com padrão de ramificação não filantóide, as inflorescências estão tanto na axila das folhas quanto na inserção das ramificações (Phyllanthus caroliniensis subsp. caroliniensis, $P$. claussenii, $P$. jacobinensis e $P$. heteradenius) 
O gênero Phyllanthus L. (Phyllantheae - Euphorbiaceae Juss.) no bioma Caatinga do estado de

Pernambuco - Brasil

Androceu - O número de estames, sua união, bem como a forma de deiscência das anteras, constituem importantes ferramentas na delimitação das espécies e dos taxa infragenéricos em Phyllanthus. Nos taxa estudados, o número de estames varia de 2-5, sendo 3 na maioria das espécies, 2 em Phyllanthus minutulus (Fig. 4, M) e 5 em $P$. jacobinensis e P. tenellus apresentando-se livres, parcial ou totalmente unidos em coluna, sempre com filetes cilíndricos e glabros. A coluna estaminal é sempre cilíndrica. Estames livres são encontrados em $P$. claussenii, $P$. heteradenius, $P$. caroliniensis subsp. caroliniensis e $P$. tenellus; parcialmente unidos em P. niruri e $P$. jacobinensis e unidos em $P$. stipulatus, P. amarus, P. acuminatus, P. minutulus e P. klotzschianus.

As anteras podem apresentar as tecas próximas entre si ou acentuadamente divergentes em $P$. claussenii. A deiscência varia de horizontal a vertical em todo o gênero (Webster, 1956). Rimas horizontais ocorrem na maioria dos taxa; verticais em $P$. jacobinensis e P. klotzschianus; oblíquas em $P$. amarus e subhorizontais em $P$. tenellus.

Disco glandular estaminado - As flores estaminadas em Phyllanthus apresentam um disco glandular extra-estaminal, bastante variável, formado, em geral, por segmentos isolados, raro unidos, sempre alternissépalos. Constitui sem dúvida, um importante caráter taxonômico, sendo utilizado por autores como Müeller (1866; 1873), Robison (1909) e Webster (1956, 1967, 1970, 1986 e 2002) na delimitação de taxa específicos e infragenéricos.

Nas espécies estudadas, o disco glandular pode ser segmentado (na maioria) ou íntegro. Nos discos segmentados o número de segmentos varia de 3 a 6 , sendo três apenas em $P$. acuminatus (Fig. 1, d), seis em $P$. caroliniensis subsp. caroliniensis (Fig. 2, d) e $P$. claussenii (Fig. 2, 1) e cinco nas demais espécies. Já disco íntegro ocorreu apenas em P. jacobinensis.

Quanto à forma, os segmentos mostraram-se bastante variáveis sendo arredondados e verruculosos em $P$. stipulatus (Fig. 5, n), trapezoidais de margens verruculosas em $P$. niruri (Fig. 5, d), globososulcados, em $P$. amarus (Fig. 1, q), obtriangulares, em $P$. caroliniensis subsp. caroliniensis (Fig. 2, d) e P. claussenii (Fig. $2,1)$ o último com superfície visivelmente verrucolosa, renifomes com superfície foveolada, em P. acuminatus (Fig. 1, d), pateliformes, em P. klotzschianus (Fig. 4, c), glandular-estipitado, em P. minutulus (Fig. 4, m) e elípticos, achatados e de ápice caudado em $P$. heteradenius (Fig. 3, d).

Sementes - As sementes em Phyllanthus ocorrem sempre aos pares em cada lóculo e possuem, em sua maioria, um esboço trígono, o qual resulta segundo Webster (1956) da compressão da parede de um lóculo do ovário contra o outro. Podem ser ainda planoconvexas em P. acuminatus (Fig. 1, m) e reniformes em $P$. jacobinensis (Fig. 3, t). A superfície da testa apresenta ornamentação bastante diversificada, consistindo numa das mais importantes ferramentas para separação das espécies. Superfície densamente verruculosa, com verrugas de formas, distribuições e dimensões variadas são encontradas em $P$. niruri (Fig. 5, j), P. heteradenius (Fig. 3, j), P. tenellus (Fig. 6, j), P. caroliniensis subsp. caroliniensis (Fig. 2, i), P. claussenii (Fig. 2, r), com estrias longitudinais semiconcêntricas em $P$. amarus (Fig. 1, v), reticulada em P. klotzschianus (Fig. 4, i), maculado em P. acuminatus (Fig. 1, m), irregularmente foveolada em $P$. jacobinensis (Fig. 3, t) e ainda com estrias transversais dispostas em fileiras longitudinais regulares em P. stipulatus (Fig. 5, t) e P. minutulus (Fig. 4, s), sendo que no primeiro as estrias são mais elevadas que no segundo. 


\section{CHAVE PARA IDENTIFICAÇÃO DAS ESPÉCIES DE PHYLLANTHUS L. OCORRENTES NO BIOMA CAATINGA EM PERNAMBUCO}

1. Plantas com cladódios 7. P. klotzschianus

1. Plantas sem cladódios 2

2. Ramificação filantóide (ramos secundários dispostos espiraladamente); presença de ramos decíduos; catafilos presentes 3

3. Arbusto ou arvoreta 2-3 m de alt.; ramos bipinatiformes; lâmina 2,1-5 cm., ápice abruptamente acuminado 1. P. acuminatus

3. Erva ou subarbusto $5-40 \mathrm{~cm}$ de alt.; ramos pinatiformes; lâmina $0,26-1,5 \mathrm{~cm}$, ápice agudo a arredondado ... 4

4. Estames 5, sempre livres; flores em címulas bissexuais e unissexuais na mesma planta; pedicelo das flores pistiladas com $(2,3)$ 4,0-6,5 $\mathrm{mm}$ compr, filiformes

11. P. tenellus

4. Estames 2 ou 3, livres ou unidos; flores em címulas bissexuais ou unissexuais; pedicelo das flores pistiladas com 0,7 a $3,1 \mathrm{~mm}$ 5

5. Lâmina com base assimétrica; estigma capitado; sementes densamente verruculosas em linhas longitudinais 9. P. niruri

5. Lâmina com base simétrica; estigma não capitado; sementes estriadas 6

6. Címula bissexual com uma flor estaminada e uma pistilada; sépalas estaminadas e pistiladas com ápice cuspidado; anteras com rimas oblíquas 2.P. amarus

6. Címula unissexual estaminada; flores pistiladas solitárias; sépalas estaminadas e pistiladas com ápice arredondado; anteras com rimas horizontais

7. Plantas com 30-45 cm alt.; estames 3; segmentos do disco glandular estaminado arredondados e verruculosos 10. P. stipulatus

7. Plantas com 5-10,5 cm alt.; estames 2; segmentos do disco glandular estaminado glandular-estipitados 8. P. minutulus

2. Ramificação não filantóide (ramos secundários dispostos de forma variada); ausência de ramos decíduos; catafilos ausentes

8. Estames 5, unidos; sementes reniformes e irregularmente foveoladas .... 6. P. jacobinensis

8. Estames 3, livres; sementes trígonas, verruculosas 9

9. Sépalas estaminadas e pistiladas 6; disco glandular estaminado 6-segmentado ..... 10

10. Arbusto ca. $1 \mathrm{~m}$; lâmina largamente elíptica a orbicular; pedicelo pistilado $0,7-1,2$ cm compr 4. P. claussenii

10. Erva 10-15 cm; lâmina elíptica a elíptico - oboval; pedicelo pistilado cerca $1 \mathrm{~mm}$ 3. P. caroliniensis subsp. caroliniensis 9. Sépalas estaminadas e pistiladas 5; disco glandular estaminado 5-segmentado 5. P. heteradenius

\section{Descrição das espécies}

Phyllanthus acuminatus Vahl, Symb. 95. 1791.

Fig. 1, a - m

Arbusto a arvoreta 2-3 m alt., monóica. Caule cilíndrico a subcilíndrico, cinéreoesverdeado, lenticelado. Ramificação filantóide. Ramos bipinatiformes, dispostos espiraladamente, decíduos após a maturação dos frutos; eixos primários $25-40 \mathrm{~cm}$ compr., eixos secundários 10-22 cm compr., ambos subcilíndricos na parte basal, angulosos próximo ao ápice, glabros a puberulentos. Catafilos ca. 2 mm compr., inconspícuos. Estípulas 1,3-1,4 mm compr., triangulares a largamente triangulares, margem levemente denticulada, 
O gênero Phyllanthus L. (Phyllantheae - Euphorbiaceae Juss.) no bioma Caatinga do estado de

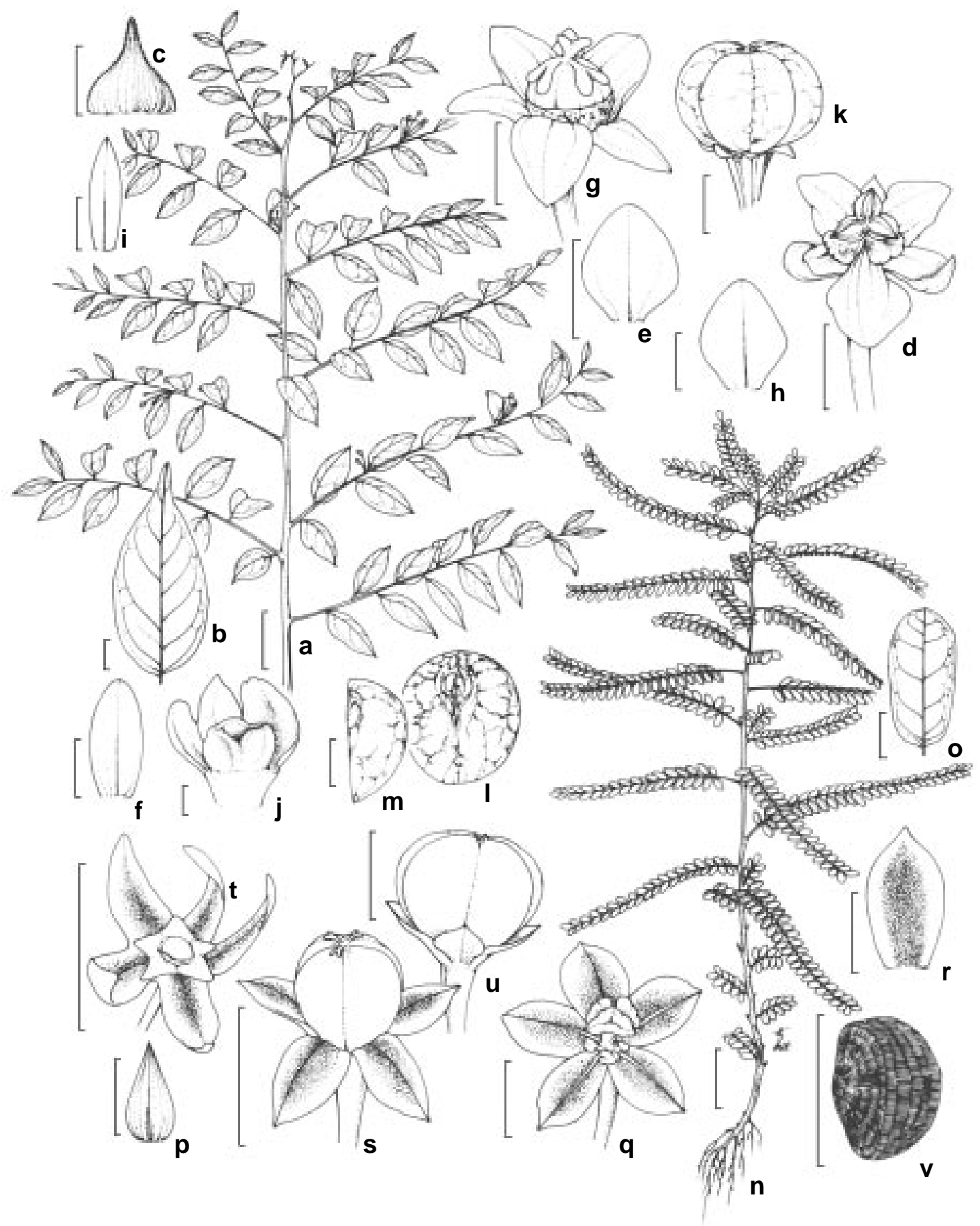

Figura 1: a - m: Phyllanthus acuminatus Vahl. a. aspecto geral do ramo bipinatiforme; b. lâmina foliar; c. estípula; d. flor estaminada; e. sépala, lobo interno, flor estaminada; f. sépala, lobo externo, flor estaminada; g. flor pistilada; h. sépala, lobo interno, flor pistilada; i. sépala, lobo externo, flor pistilada; j. disco glandular pistilado, aspecto; k. fruto; 1. detalhe das sementes ao saírem do lóculo; $\mathrm{m}$. aspecto da semente. $\mathrm{n}-\mathrm{v}$ : P. amarus Schumach. \& Thonn. $\mathrm{n}$. hábito; o. lâmina foliar; $\mathrm{p}$. estípula; q. flor estaminada; r. sépala, face ventral evidenciando a faixa central, flor estaminada; s. flor pistilada; t. aspecto do disco glandular pistilado; $u$. fruto; v. semente, aspecto dorsi-ventral. (Escalas: $\mathrm{a}, \mathrm{n}=2 \mathrm{~cm} ; \mathrm{b}=3 \mathrm{~mm} ; \mathrm{c}, \mathrm{d}, \mathrm{e}, \mathrm{g}, \mathrm{k}, 1, \mathrm{~m}$, $\mathrm{o}, \mathrm{p}, \mathrm{s}, \mathrm{t}, \mathrm{u}, \mathrm{v}=1 \mathrm{~mm} ; \mathrm{f}, \mathrm{h}, \mathrm{i}, \mathrm{j}, \mathrm{q}=0,5 \mathrm{~mm} ; \mathrm{r}=0,4 \mathrm{~mm})$

Rodriguésia 55 (84): 101-126. 2004 
persistentes. Pecíolo 1,4-2 mm compr., aplainado, puberúlo abaxialmente e glabro adaxialmente. Lâmina 2,1-5 x 1,4-2,5 cm., membranácea, oval a oval-elíptica, base obtusa a arredondada, ápice abruptamente acuminado, margem inteira, glabra em ambas as faces, discolor, face adaxial verdeescura, abaxial verde-glauca; venação broquidódroma. Címulas bissexuais, congestas, curtamente pedunculadas, com 5-6 conjuntos estaminados, cada um com 4-6 flores, flor pistilada 1 , longamente pedicelada, solitária na parte central; brácteas elípticas $0,5-0,7 \mathrm{~mm}$ compr., hialinas. Flores estaminadas, pedicelo 2,9-4 mm compr., filiforme, glabro; sépalas 6, bisseriadas; lobos externos 1-1,1 mm compr., oblongo-elípticos, ápice agudo, carenados dorsalmente, nervura central evidente, margens amareladas; lobos internos ca. $1 \mathrm{~mm}$ compr., ovais, faixa central oblonga, com margem ondulada e ápice arredondado; disco glandular 3 -segmentado, segmentos reniformes, carnosos, superfície foveolada; estames 3, unidos em coluna; anteras patentes, oval-triangulares, ápice fortemente apiculado, rimosas longitudinalmente. Flores pistiladas, pedicelo $8,2-11 \mathrm{~mm}$ compr., filiforme, discretamente anguloso, pubescente; sépalas 6, bisseriadas; lobos externos 1,7-1,8 mm compr., oblongo-elípticos, nervura central evidente; lobos internos 1,1-1,5 mm compr., elípticos a trulados, discretamente venados; disco glandular 3-segmentado, segmentos unidos na base, orbiculares, ovário ca.1 mm compr., oblato; estilete 3, livres, bilobados, apressos. Cápsula 3,9$4 \mathrm{~mm}$ compr., ca.5 mm diâm., oblata, discretamente venulada, verde-escura. Sementes 2,3-2,5 mm compr., plano-convexas, fortemente unidas aos pares o que lhes confere um aspecto globoso, lisas, castanho-avermelhadas, maculadas.

Material examinado: BRASIL. PERNAMBUCO: Altinho, 10/IV/02, bot., fl., fr., M. J. Silva 189 (PEUFR); idem, 10/IV/02, bot., fl. fr., M. J. Silva 190 (PEUFR); Bonito, 21/V/96, bot., fl.fr., Lira 178 (PEUFR); Brejo da madre de Deus, 15/III/96, fl. fr., Hora et al.. 90 (PEUFR); idem, 15/III/96, fl. fr., F. Lucena 132 (PEUFR); idem, 15/III/96, fl. fr.,
M. Oliveira et al. 236 (PEUFR); Caruaru, 05/XI/01, veg., M. J. Silva 150 (PEUFR); Vicência, 26/VIII/02, fl. fr., M. J. Silva 198, 199 (PEUFR). Material adicional examinado: BRASIL. ALAGOAS: São José da Lage, 26/II/02, fl. fr., M. Oliveira \& A. A. Grilo 766 (UFP); idem, 27/II/02, fl. fr., M. Oliveira \& A. A. Grilo 790 (UFP); BAHIA: São Gonçalo dos Campos, 10/II/83, fl., Pinto et al. 360/86 (HRBN).

Espécie amplamente distribuída desde o norte do México até a Argentina, incluindo Antilhas (Webster, 1956). No Brasil é referida por Müeller (1873) para os estados de Minas Gerais, Rio de Janeiro, São Paulo, Bahia, Mato Grosso e Distrito Federal, onde ocorre em florestas úmidas perenifólias. $\mathrm{Na}$ área de estudo é encontrada apenas nas florestas Montanas (Brejos de Altitude, 870-1.050 m de altitude) em trilhas, no interior da mata ou em suas bordas, em solos do grupo Latosssolo, em geral úmidos e ricos em serrapilheiras.

Apresenta afinidades com Phyllanthus subglomeratus (Antilhas), com a qual compartilha o hábito arbustivo a arbóreo e o padrão de ramificação filantóide com ramos bipinatiformes e o cálice bisseriado. No entanto, diferencia-se por apresentar o disco glandular estaminado constituído por três segmentos livres, reniformes com superfície foveolada, as anteras apiculadas e as folhas ovais a ovalelípticas de ápice abruptamente acuminado, o que a torna facilmente reconhecível. Em $P$. subglomeratus o disco estaminado é íntegro e cupuliforme, as anteras são emarginadas e as folhas são elípticas de ápice agudo. Das espécies estudadas, distingui-se pela ramificação filantóide com ramos bipinatiformes, flores com cálice bisseriado e dispostas em címulas congestas, bem como pelas sementes plano-convexas destituídas de ornamentação e fortemente unidas aos pares, que lhe confere aspecto globoso. Floresce e frutifica em fevereiro, março e novembro. $\ddot{\mathrm{E}}$ conhecido popularmente como Chilillo e galina (Costa Rica) e Tinguí e mata - peixe (PE). 
O gênero Phyllanthus L. (Phyllantheae - Euphorbiaceae Juss.) no bioma Caatinga do estado de

Pernambuco - Brasil

Phyllanthus amarus Schumach. \& Thonn., Kongel. Dasnke Vidensk.-Selsk. Skr. 4: 195196. 1829.

Fig. 1, n-v

Erva a subarbusto 3,5-60 cm alt., ereta, anual, monóica, glabra. Caule cilíndrico, cinéreo-esverdeado a verde-avermelhado, esparso a densamente ramificado. Ramificação filantóide. Ramos 1,3-8,5 cm compr., pinatiformes, decíduos, subcilíndricos, esverdeados. Catafilos 0,8-1 mm compr., largamente triangulares, acuminados, escariosos. Estípulas 0,9-1,0 mm compr., oval-lanceoladas a lanceoladas, acuminadas, membranáceas, persistentes. Pecíolo 0,4-0,5 mm compr., subcilíndrico. Lâmina 4,7-8,0x 2,6-4,0mm compr., membranácea, oblonga a oblongo-obovada, base arredondada, simétrica, ápice obtuso a arredondado, margem inteira, discolor, face adaxial verde-escura, abaxial verde-glauca; venação broquidódroma. Címulas bissexuais, com uma flor estaminada e uma pistilada, dispostas ao longo dos ramos; brácteas ca.0,3 $\mathrm{mm}$ compr., lineares. Flores estaminadas, pedicelo 0,5-0,6 mm compr., cilíndrico, verdeclaro; sépalas 5, com 0,5-0,6 mm compr., oblongo-elípticas, ápice cuspidado, faixa central oblonga, esverdeada, margem esbranquiçada; disco glandular 5-segmentado, segmentos livres, globoso-sulcados, carnosos; estames 3, completamente unidos em coluna, anteras sésseis no topo da coluna, rimas oblíquas. Flores pistiladas, pedicelo $0,7-1,2 \mathrm{~mm}$ compr., cilíndrico a anguloso; sépalas 5, com 0,7-0,8 mm compr., oblongas, ápice cuspidado, faixa central oblonga, esverdeada, margem esbranquiçada; disco glandular profundamente 5-segmentado; ovário ca.0,4 mm compr., globoso; estiletes 3, livres, bífidos, suberetos a apressos, estigma levemente bilobado. Cápsula 1-1,3 mm compr., 1,7-1,8 mm diâm, oblata. Sementes 0,9-1 mm compr., trígonas, castanho-claras, com estrias longitudinais semiconcêntricas e numerosas estrias transversais muito aproximadas.

Material examinado: BRASIL. PERNAMBUCO: Alagoinha, 09/IV/02, fl. fr., M. J, Silva 172, 173, 174, 175, 176, 177
(PEUFR); Betânia, 25/VIII/01, fl. fr., M. J. Silva 119, 120, 121, 124 (PEUFR); Caruaru, 06/I/02, fl. fr., M. J. Silva 150, 151, 152, 153, 154, 155, 156, 157 158, 159 (PEUFR); Custódia, 12/X/02, fl. fr., M. J. Silva 233, 234, 235, 236 237, 238, 239, 240 (PEUFR); Goiana, 20/XI/ 02, fl. fr., M. J. Silva 268, 269, 270, 271, 272, 273, 274 (PEUFR); Limoeiro, 21/IX/01, fl. fr., M. J. Silva 128 (PEUFR); Petrolina, 20/XI/83, Fl., fr, Fortius 3596 (IPA); idem, 06/IX/02, fl. fr., M. J. Silva 227, 228, 229, 230 (PEUFR); Recife, 05/VIII/58, fl. fr., A. Lima s/n (PEUFR); idem, 22/VIII/02, fl. fr., M. J. Silva 215, 216 (PEUFR); Nazaré da Mata, 04/X/58, fl. fr., A. Lima s/n (PEUFR). Material adicional examinado: BRASIL. ALAGOAS: São José da Laje, 20/II/02, fl. fr., M. Oliveira \& A. A. Grilo 771 (UFP). SERGIPE: Canindé do São Francisco, 26/V/ 99, fl. fr., Silva et al. 403 (PEUFR, UFP). PIAUÍ: Teresina, 07/III/99, fl. fr., Filho 25 (PEUFR); idem, 18/XII/99, fl. fr., Lopes Sobrinho et al.. s/n (PEUFR).

Distribuição pantropical. Nas Américas ocorre desde os Estados Unidos até a Argentina, incluindo Antilhas. No Brasil é referido para Alagoas, Bahia, Pernambuco, Piauí, Rio Grande do Sul, Santa Catarina (Filho, 2000; Smith \& Downs, 1959; Allem, 1977). Em Pernambuco é encontrada desde o litoral até o sertão, em geral associada a ambientes perturbados, ocorrendo em canteiros de jardins, margens de estradas e calçadas, além de ser invasora em áreas de cultivos.

Apesar de $P$. amarus ter sido tratada como sinônimo de P. niruri (Müeller, 1873), não apresenta tantas proximidades com esta espécie, embora compartilhem o mesmo hábito, forma de vida e padrão de ramificação. Mostra maiores afinidades com Phyllanthus abnormis Baill. (Antilhas), por ambas serem as únicas do gênero a apresentar címulas bissexuais constituídas por uma flor pistilada e uma flor estaminada e terem, em comum, o mesmo aspecto morfológico, hábito e forma de vida, diferindo apenas pelo número de sépalas estaminadas, quatro em P. abnormis 
e cinco em $P$. amarus e pelo comprimento do pedicelo (Webster, 1958). Pode ser reconhecida pelos lobos cuspidados do cálice em ambos os tipos de flores, pelas anteras oblíquas e sementes com estrias longitudinais semiconcêntricas e numerosas estrias transversais muito aproximadas. Floresce e frutifica durante todo ano. Em Pernambuco é conhecida popularmente como quebra-pedra e comumente utilizada na medicina popular, em geral no tratamento de patologias associadas ao sistema urinário e, ainda, como abortivo.

Phyllanthus caroliniensis Walt. subsp. caroliniensis, Flora Caroliniana 228. 1788.

Fig. 2, a - i

Erva $10-15 \mathrm{~cm}$ alt., ereta, anual ou perene, monóica, glabra. Caule cilíndrico, ramificado desde a base. Ramificação não filantóide. Ramos 3-5 cm compr., cilíndricos, arranjados disticamente, atingindo quase a mesma altura, $o$ que confere a planta um aspecto pinatiforme, amarronzados a violáceos, presença de folhas desenvolvidas no caule principal. Catafilos ausentes. Estípulas 1-1,1 mm compr., persistentes, triangulares, acuminadas, levemente auriculadas na base, margem levemente denticulada, escariosas, róseas a vináceas. Pecíolo 1-1,3mm compr., subcilíndrico. Lâmina 6-15 x 3-7mm., membranácea, elíptica a elíptico-oboval, base aguda a obtusa, ápice obtuso, margem inteira, levemente vinácea; venação broquidódroma. Címulas bissexuais na axila da folhas e dos ramos, com (1) - 2 flores estaminadas e 2 - (1) pistilada; brácteas 0,5-0,6 mm compr., triangulares, escariosas, margem levemente lacerada, róseas. Flores estaminadas, pedicelo 0,9-1,2 mm compr., cilíndrico; sépalas 6 , com 0,8 - 1 x 0,5 - 0,6 mm compr., obovais a suborbiculares, raro largamente elípticas, ápice arredondado, nervura central evidente, branco-róseas ou amareladas; estames 3 , livres, anteras com rimas horizontais; disco glandular 6-segmentado, segmentos obtriangulares. Flores pistiladas, pedicelo 0,7-0,8 mm compr., geniculado no fruto, recurvado, rígido; sépalas 6, com 0,9-1 mm compr., oblongoespatuladas, faixa central oblongo-espatulada, verdes a vináceas; disco glandular cupuliforme, margem levemente lobada; ovário ca. $0,3 \mathrm{~mm}$ compr., depresso-oval; estiletes 3, livres, bífidos, apressos, estigma subcapitado, cálice acrescente e estiletes persistentes no fruto. Cápsula ca. 1 mm compr., 1,7-1,9 mm diâm, depresso-oval, verde-avermelhada. Sementes 0,9-1 mm compr., trígonas, diminutamente verruculosas ao longo de fileiras longitudinais regulares, castanho-claras, brilhosas.

Material examinado: BRASIL. PERNAMBUCO: Caruaru, 25/VII/01, fl. fr., M. J. Silva 100, 101, 102, 108 (PEUFR); idem, 05/X/01, fl. fr., M. J. Silva 142, 143, 148, 149 (PEUFR); idem, 10/IV/02, fl. fr., M. J. Silva 185, 186, 187 (PEUFR); Petrolina, 04/III/83, fl. fr., Fortius 3367 (IPA); São Benedito do Sul, 23/XI/02, fl. fr., M. J. Silva 286 (PEUFR); São Lourenço da Mata, 30/XI/02, fl. fr., M. J. Silva 289, 290, 291, 292, 302, 304, 305 (PEUFR). Material adicional examinado: BRASIL. ALAGOAS: São José da Laje, 26/II/02, fl. fr., M. Oliveira \& A. A. Grilo 779 (UFP).

Amplamente distribuída nas Américas desde os Estados Unidos e América Central, incluindo Antilhas, até a Argentina, ocorrendo em diversos tipos vegetacionais (florestas perenifólias, semi-decíduas e decíduas). No Brasil é referida para as regiões Nordeste (AL, PE), Centro - Oeste (DF), Sudeste (SP) e Sul (RS, SC). Na área de estudo ocorre tanto em áreas de caatingas devastadas, em locais úmidos à sombra de arbustos, como nas florestas Montanas, onde cresce como invasora de culturas ou nas margens de estradas e canteiros de jardins, ou ainda próximo às margens de rios.

Webster (1970) reconhece para esta espécie três subespécies: $P$. caroliniensis subsp. caroliniensis, $P$. caroliniensis subsp. saxicola e $P$. caroliniensis subsp. stenopterus., baseado principalmente na densidade de ramificação do caule, na forma dos ramos e do limbo foliar e na presença de indumento. $\mathrm{Na}$ área de estudos todos os indivíduos analisados pertencem a $P$. caroliniensis subsp. caroliniensis. 
O gênero Phyllanthus L. (Phyllantheae - Euphorbiaceae Juss.) no bioma Caatinga do estado de Pernambuco - Brasil

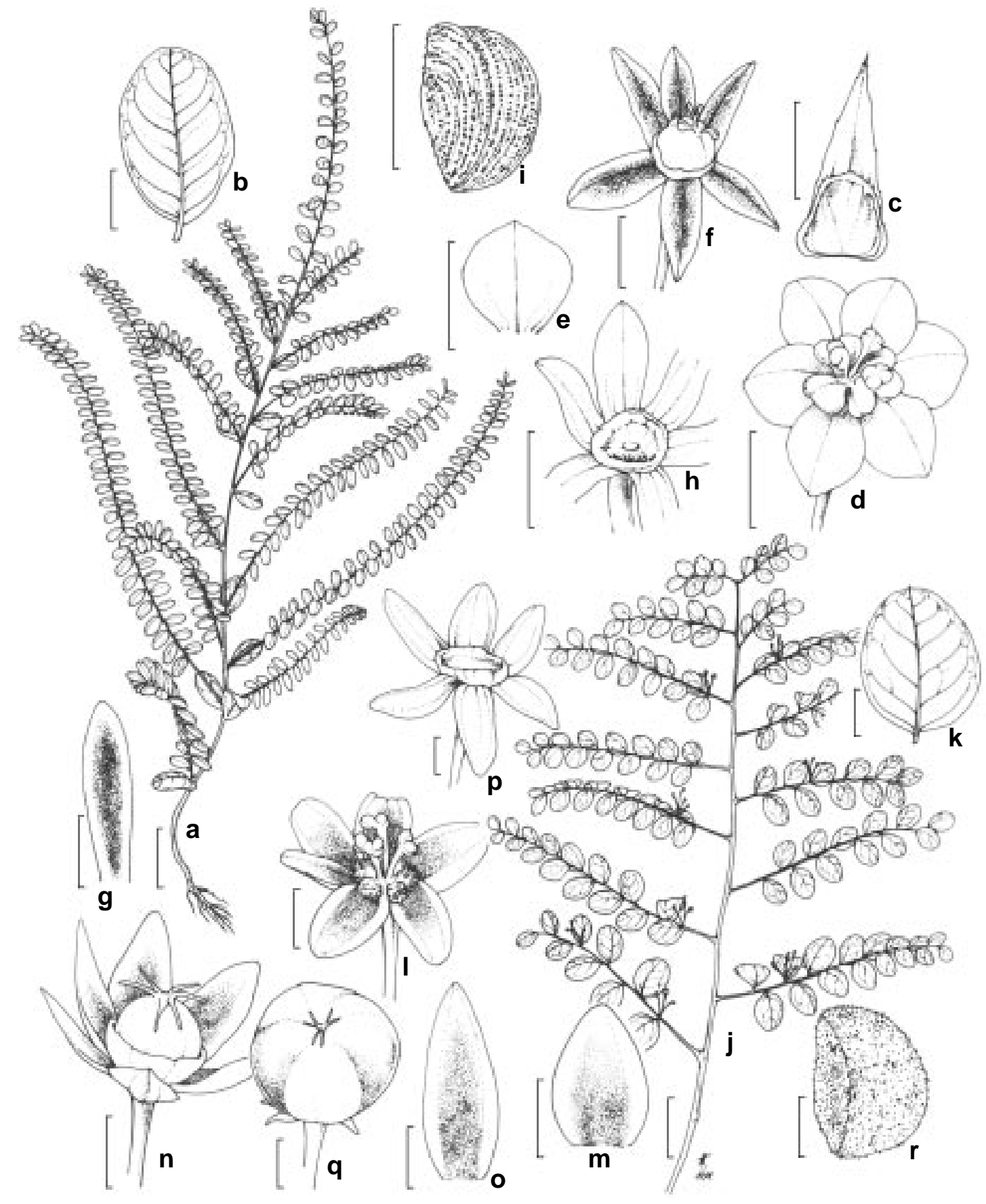

Figura 2: a - i: Phyllanthus caroliniensis Walt. subsp. caroliniensis. a. hábito; b. lâmina foliar; c. estípula; d. flor estaminada; e. sépala, flor estaminada; f. flor pistilada; g. sépala, face ventral evidenciando a faixa central, flor pistilada; $h$. disco glandular pistilado, aspecto; i. aspecto geral da semente. j - r: P. claussenii Müll. Arg. j. aspecto geral do ramo florido; k. lâmina foliar; 1. flor estaminada; m. sépala, face central evidenciando a faixa central, flor estaminada; $\mathrm{n}$. flor pistilada; o. sépala, face ventral evidenciando a faixa central, flor pistilada; p. disco glandular pistilado, aspecto; q. fruto; r. semente face dorsi-ventral. (Escalas: $a, j=2 \mathrm{~cm} ; \mathrm{b}, \mathrm{k}=2 \mathrm{~mm} ; \mathrm{c}, \mathrm{d}, \mathrm{e}, \mathrm{f}, \mathrm{g}, \mathrm{l}, \mathrm{m}, \mathrm{n}, \mathrm{o}, \mathrm{p}, \mathrm{r}=0,5 \mathrm{~mm} ; \mathrm{h}, \mathrm{i}, \mathrm{q}=1 \mathrm{~mm}$ ) 
Phyllanthus caroliniensis foi posicionada por Webster (1956) no subgênero Isocladus, seção Loxopodium, a qual reúne espécies caracterizadas principalmente pelas folhas e ramos dísticos, flores produzidas tanto nas axilas das folhas quanto na inserção dos ramos, ausência de catafilos e flores pistiladas com pedicelo geniculado no estágio de frutificação. É facilmente reconhecido pelos ramos sempre dísticos conferindo a planta um aspecto pinatiforme, pelo pedicelo pistilado geniculado no estágio de frutificação e ainda por apresentar os lacínios do cálice em número de seis (num único verticilo) nas flores de ambos os sexos. Apresenta maiores afinidades com $P$. heteradenius por ambas terem em comum a produção de flores tanto nas axilas das folhas quanto na inserção dos ramos, o mesmo número de estames (3), e o padrão de ramificação não filantóide, embora difiram fortemente quanto ao modo de distribuição dos ramos, aspecto do disco estaminado e pistilado, quanto à forma, número e consistência das sépalas pistiladas e aspecto do pedicelo pistilado. Floresce e frutifica em março, julho, novembro e dezembro.

Phyllanthus claussenii Müll. Arg., Linnaea 32: 40.1863.

Fig. 2, j - r

Arbusto ca. $1 \mathrm{~m}$ alt., ereto, monóico. Caule cilíndrico, densamente ramificado, marrom-avermelhado, com fissuras. Ramificação não filantóide. Ramos patentes a subpatentes, cilíndricos, marromavermelhados, discretamente fissurados, glabros. Catafilos ausentes. Estípulas ca. 1,1 $\mathrm{mm}$ compr., triangulares, ápice acuminado, margens inteiras, escariosas; pecíolo 1,0-1,3 mm compr., cilíndrico, glabro, esverdeado. Lâmina $\quad 0,8-1 \quad$ x $\quad 0,7-1 \quad \mathrm{~cm}$ compr., membranácea, largamente elíptica a orbicular, base obtusa, ápice obtuso a arredondado, margem inteira, discolor, face adaxial verdeescura, abaxial verde-cinérea; venação broquidódroma. Címulas bissexuais, constituídas de uma flor pistilada com pedicelo filiforme, circundada por duas címulas estaminadas com 2-3 flores cada; brácteas ca. de $1 \mathrm{~mm}$ compr., lineares, escariosas. Flores estaminadas, pedicelo 1,2-1,6 mm compr., filiforme, creme; sépalas 6 , ca. 1,1 mm compr., elípticas, ápice agudo, nervura central evidente; disco glandular, 6-segmentado, segmentos obtriangulares com superfície verruculosa; estames 3, livres, anteras com tecas divergentes, rimas horizontais. Flores pistiladas, pedicelo 0,7-1,2 cm compr.; sépalas 6 , com 0,8 1,2 mm compr., elíptico-ovais, ápice agudo a obtuso, faixa central estreitamente triangular a elíptica; disco glandular, pateliforme, delgado, margem discretamente lobada; ovário ca. $1 \mathrm{~mm}$ compr., depresso-globoso, visivelmente 3sulcado; estiletes 3 , livres, profundamente bífidos, ramos patentes, estigmas puntiformes. Cápsula 1-1,2 mm compr., 1,9-2,1 mm diâm, oblata, verde-clara, glabra. Sementes 1,1-1,2 mm compr., trígonas, irregular e esparsamente verruculosas, castanho-claras a escuras.

Distribuição exclusivamente brasileira, sendo referida por Webster (2002) para as regiões Nordeste (CE e PE) e Sudeste (SP, MG e ES), com ocorrência nos domínios do cerrado e da caatinga, em altitudes que variam de 500 a $1.100 \mathrm{~m}$, em matas ou bosques abertos. $\mathrm{Na}$ área de estudo é encontrada na subzona do Sertão, em vegetação de Caatinga.

Caracteriza-se por ser um arbusto densamente ramificado com ramificação não filantóide, pelos três estames, livres, com tecas divergentes, flores estaminadas e pistiladas com seis sépalas, e disco glandular estaminado com seis segmentos obtriangulares. Apresenta maiores afinidades com $P$. subemarginatus por ambas compartilharem o mesmo aspecto vegetativo, forma de folha, tipo de inflorescência, número de estames e deiscência das anteras, embora $P$. subemarginatus difira pelo número de sépalas (5) em ambas as flores e pela diocia.

Material examinado: BRASIL. PERNAMBUCO: Arcoverde, 08/V/56, fl. fr., Andrade-Lima 56-2560 (IPA); Santa Terezinha, 20/03/01, fl. fr., A. P. S. Gomes 722 
O gênero Phyllanthus L. (Phyllantheae - Euphorbiaceae Juss.) no bioma Caatinga do estado de

Pernambuco - Brasil

(PEUFR); São José do Belmonte, 09/ IV/02, fl. fr., A. Laurênio 1823 (PEUFR); idem, 13/ V/71, fl. fr., E. P. Heringer et. al. 738 (IPA).

Phyllanthus heteradenius Müll. Arg., Fl. bras. 11(2): 63. 1873.

Fig. 3, a - j

Erva 8,5-15,5 cm alt., anual, ereta, monóica, glabra. Caule esparso a densamente ramificado. Ramificação não filantóide. Ramos 3-7,5 mm compr., persistentes, com flores de um só sexo, verde-vináceos. Catafilos ausentes. Folhas desenvolvidas ao longo do caule principal; estípulas 0,8-1 mm compr., ovais, acuminadas, margem levemente lacerada, avermelhadas; pecíolo 0,6-1,1 mm compr., subcilíndrico, verde a vináceo; lâmina 4-11 x 3-6 mm, membranácea, largamente elíptica a orbicular, base aguda a obtusa, ápice agudo a arredondado, margem inteira, levemente vinácea na parte apical, discolor, face adaxial verde-escuro, abaxial verde-glauca; venação broquidódroma. Címulas estaminadas 2-4 flores; brácteas 0,7-1 mm compr., triangulares, escariosas, vináceas. Flores estaminadas, pedicelo 0,6-0,7 $\mathrm{mm}$ compr., anguloso; sépalas 5, com 1-1,1 mm compr., obovais, ápice cuspidado, faixa central elípticaoboval; disco glandular 5-segmentado, segmentos livres, elípticos, achatados, ápice caudado; estames 3, livres, anteras com tecas divergentes, rimas horizontais. Flores pistiladas, solitárias, dispostas ao longo dos ramos; pedicelo 1,4-2 mm compr.; sépalas 5, com 0,9-1 mm compr., obtruladas a obovais, fortemente venadas, foliáceas, verde-escuras; disco glandular 5segmentado, segmentos largamente ovais, adnados na base; ovário 0,4-0,5 mm diâm., oblato; estiletes 3 , livres, bífidos, patentes a ascendentes, com ramos encurvados um em direção ao outro; estigma capitado. Cápsula 2,1-2,4 mm diâm, depresso-ovóide, cálice acrescente e estiletes persistentes. Sementes 1-1,1 mm compr., trígonas, levemente côncavas no dorso, com margens ligeiramente quilhadas, ornadas com 6-7 linhas longitudinais minutamente verruculosas, castanho-escuras.
Material examinado: BRASIL. PERNAMBUCO: Afrânio, 19/IV/71, fl. fr., E. P. Heringer et al.. 155 (IPA); idem, 24/IV/ 71, fl. fr., E. P. Heringer et. al. 333 (IPA); Alagoinha, 09/IV/02, fl. fr., Silva, M. J, 165, 166, 167, 168, 169, 170, 171 (PEUFR); Betânia, 25/VIII/01, fl. fr., Silva, M. J. 116, 117, 118, 122, 123, 126, 127 (PEUFR); Petrolina, 21/03/74, fl. fr., Fortius 3803 (IPA); Serra Talhada, 05/II/98, fl., A. Laurênio, Andrade \& Sacramento 735 (PEUFR). Material adicional examinado: BRASIL. ALAGOAS: Piranhas, 12/VIII/99, fl. fr., Silva \& Moura 817 (PEUFR, UFP). SERGIPE: Canindé do São Francisco, 03/VIII/1999, fl. fr., Silva \& Moura 779 (PEUFR, UFP); idem, 08/ VI/99 fl. fr., Silva \& Sales 481 (PEUFR, UFP).

Exclusiva do Brasil (Nordeste), em vegetação de Caatinga hiperxerófila e cerrado nos estados de Alagoas, Bahia, Pernambuco, Paraíba e Sergipe (Wesbter, 2002). Em Pernambuco, foi encontrada na subzona do Sertão, em vegetação de caatinga, na sombra de arbustos ou arvoretas, em geral em solos arenosos.

Apresenta afinidades com Phyllanthus atalaiensis Webster, no entanto difere do mesmo por apresentar folhas glabras, disco glandular estaminado com seguimentos elípticos, achatados e de ápice caudado, além das estípulas aglandulares e de margem levemente laceradas. Distingui-se das demais espécies estudadas por apresentar flores pistiladas e estaminadas em ramos distintos (nunca os dois tipos florais no mesmo ramo), pelas flores pistiladas com sépalas foliáceas, fortemente venadas e verde-escuras, além das sementes verruculosas com dorso côncavo e margens ligeiramente quilhadas. Floresce e frutifica em fevereiro, abril, maio e agosto.

Phyllanthus jacobinensis Müll. Arg., Linnaea 32: 6. 1863.

Fig. 3, k - t

Arbusto 1-1,20 m alt., ereto, monóico, densamente ramificado. Ramificação não filantóide. Ramos patentes a subpatentes, cilíndricos, cinéreo-avermelhados a 


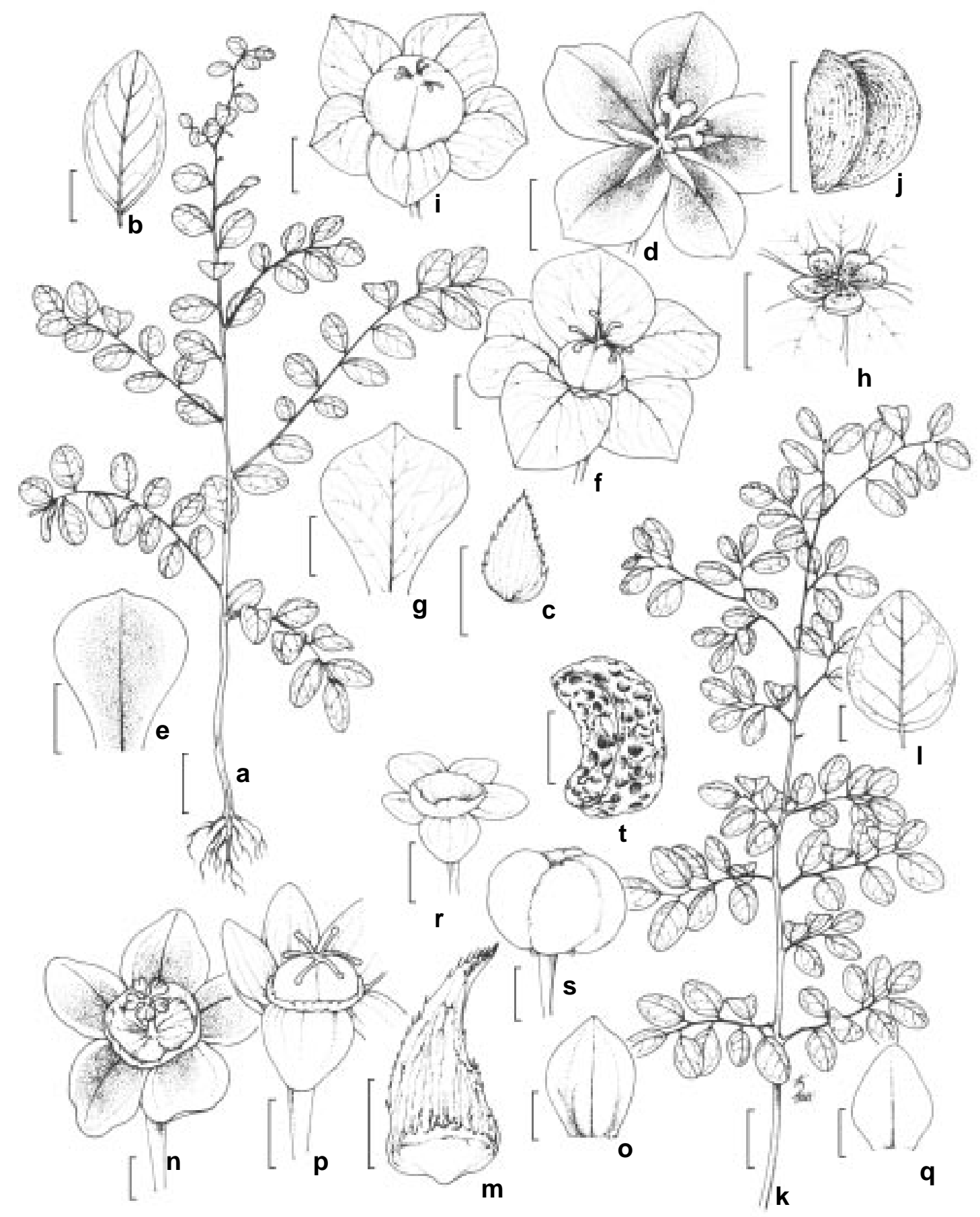

Figura 3: a-j: Phyllanthus heteradenius Müll. Arg. a. hábito; b. lâmina foliar; c. estípula; d. flor estaminada; e. sépala, face ventral evidenciando a faixa central, flor estaminada; f. flor pistilada; g. sépala, face ventral evidenciando a venação, flor pistilada; h. disco glandular pistilado, aspecto; i..fruto; j. semente aspecto dorsi-ventral. $\mathrm{k}$ - t: P. jacobinensis Müll. Arg. k. aspecto geral do ramo; l. lâmina foliar; m. estípula; $n$. flor estaminada; o. sépala, face ventral evidenciado a faixa central, flor estaminada; p. flor pistilada; q. sépala, flor pistilada; r. disco glandular pistilado, aspecto; s. fruto; t. semente, aspecto geral. (Escala: a, $\mathrm{k}=2 \mathrm{~cm} ; \mathrm{b}, \mathrm{l}=4 \mathrm{~mm} ; \mathrm{c}, \mathrm{d}, \mathrm{f}, \mathrm{g}, \mathrm{h}, \mathrm{i}, \mathrm{j}, \mathrm{p}, \mathrm{r}, \mathrm{t}=1 \mathrm{~mm} ; \mathrm{e}, \mathrm{m}, \mathrm{o}, \mathrm{q}=0,5 \mathrm{~mm} ; \mathrm{n}, \mathrm{s}=2 \mathrm{~mm}$ ) 
O gênero Phyllanthus L. (Phyllantheae - Euphorbiaceae Juss.) no bioma Caatinga do estado de

amarronzados com fissuras, papilosos nas partes jovens. Catafilos ausentes. Estípulas 1,2$1,4 \mathrm{~mm}$ compr., triangulares, ápice acuminado, levemente deflexas, margens laceradas, escariosas. Pecíolo 1,2-1,3 mm compr., subcilíndrico, papilosos. Lâmina 1,1-4,2 x 1,1$2,3 \mathrm{~cm}$, membranácea, oval a oval-elíptica, base arredondada a oblíqua, ápice agudo a arredondado, margem inteira, concolor; venação broquidódroma. Címulas bissexuais constituídas de uma flor pistilada e 1-3 flores estaminadas; brácteas 1-1,1 mm compr., triangulares, margem lacerada. Flores estaminadas, pedicelo 0,4-1,2 cm compr., filiforme, creme; sépalas 5, ca. 1,1 mm compr., largamente elípticas a obovais, ápice arredondado, faixa central da mesma forma das sépalas; disco glandular amplamente orbicular; estames 5, unidos em coluna, anteras com rimas horizontais. Flores pistiladas, visivelmente articuladas, pedicelo $3-4,1 \mathrm{~cm}$ compr., filiforme, esverdeado, atingindo $4,6 \mathrm{~cm}$ compr. no estádio de frutificação; sépalas 5, com 1-1,1 mm compr., ovais, ápice arredondado, faixa central oval-elíptica; disco glandular anular; ovário ca. $1 \mathrm{~mm}$ compr., depresso-globoso; estiletes 3, livres, profundamente bipartidos, ramos subpatentes, estigmas capitados. Cápsula 4,5-5 mm compr., 5,8-6 mm diâm., carnosa. Sementes 2,1-2,3 mm compr., reniformes, irregularmente foveoladas, castanho-claras.

Material examinado: BRASIL. PERNAMBUCO: Caruaru, 30/X/99, fl. fr., M. J. Silva 36, 38, 41 (PEUFR); idem, 25/VII/ 01, fl. fr., M. J. Silva 105, 107 (PEUFR); idem, 10/VII/80, fl., fr., A. Lima et al. 02 (IPA); Limoeiro, 21/IX/01, fr., M. J. Silva 129 (PEUFR); São bento do Una, 14/ VII/80, fl. fr., A. Lima et al. 2 (IPA).

Referida apenas para o Brasil (MG e BA) por Müeller (1873), e registrada pela primeira vez para Pernambuco neste trabalho. Em Pernambuco foi coletada em vegetação de caatinga nos municípios de Caruaru e Limoeiro; no primeiro cresce próximo a rochas em solos areno-pedregosos, com serrapilheiras e úmidos; no segundo ocorre em áreas de serras, em solos areno-argilosos, sobre a sombra de arvoretas.

Caracteriza-se, principalmente, por ter hábito arbustivo, flores estaminadas com 5 estames unidos em coluna e disco glandular amplamente orbicular, flores pistiladas com estiletes profundamente bipartidos, além de sementes reniformes e foveoladas. Pode apresentar caducifolia durante o período de estiagem na Caatinga. Floresce e frutifica em julho, outubro e novembro.

Phyllanthus klotzschianus Müll. Arg., Linnaea 32: 53.1863

Fig. 4, a - i

Subarbusto ca. $80 \mathrm{~cm}$ alt., ereto, monóico, glabro. Caule cilíndrico, cinéreo, densamente fissurado. Catafilos 1-2 mm compr., largamente triangulares, coriáceos, ápice agudo, dispostos na inserção dos cladódios. Ramificação filantóide. Ramos bipinatiformes, modificados em cladódios. Cladódios, 4,5-14,1 x 0,3-0,7 cm, estreitamente lanceolados a lineares, laminares, base atenuada, ápice obtuso, coriáceos, verde-escuros. Címulas estaminadas 1-2 flores, sésseis; sépalas 5, com 1,2-2 mm compr., oblongo-obovais, discretamente venadas; disco glandular 5segmentado, segmentos pateliformes; estames 3 , unidos em coluna; anteras com tecas assimétricas, rimas verticais a oblíquas. Flores pistiladas, solitárias, sésseis; sépalas 5, com 2,9$3,1 \mathrm{~mm}$ compr., oblongo-obovais a largamente obovais, discretamente venadas; disco glandular cupuliforme, margem levemente lobada; ovário ca. $1 \mathrm{~mm}$ compr., depresso-oval a oblato; estiletes 3, livres, eretos, profundamente bífidos, estigma obtuso. Cápsula ca. 2,8 mm compr., 3,8-4,1 mm diâm., oblata, vinácea. Sementes 2-2,2 mm compr., trígonas, discretamente reticuladas, castanhoescuras.

Material examinado: BRASIL. PERNAMBUCO: Afrânio, 24/IV/71, fl. fr, Heringer et al. s/n (IPA); Buíque, 07/X/60, fl. fr, Fortius 3803 (IPA); idem, 07/IX/60, fl., A. 


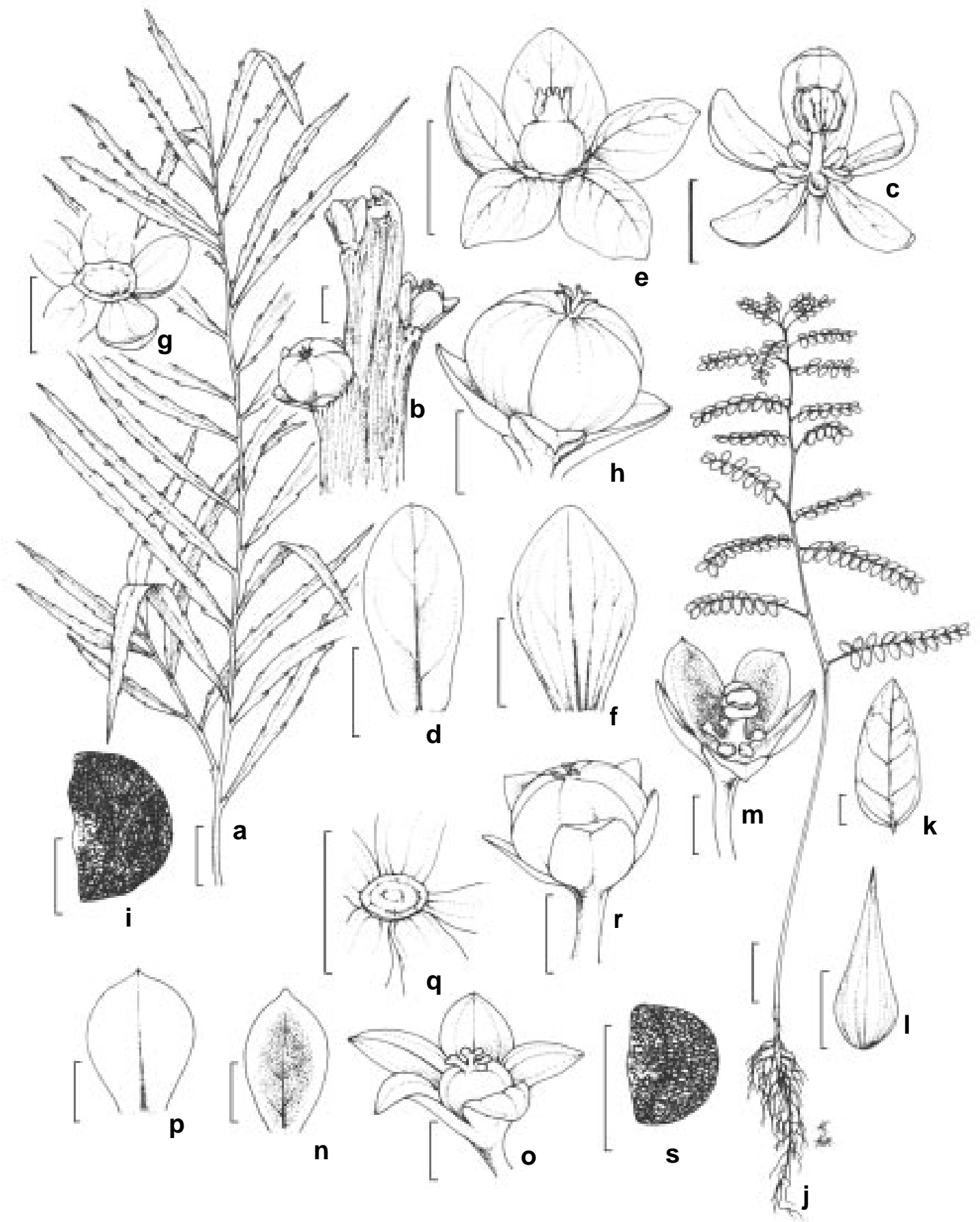

Figura 4: a -i: Phyllanthus klotzschianus Müll. Arg. a. aspecto geral do ramo florido; b. detalhe do cladódio evidenciando a disposição das flores; c. flor estaminada; d. sépala, face ventral evidenciando a faixa central, flor estaminada; e. flor pistilada; f. sépala, face ventral evidenciando a faixa central, flor pistilada; g. disco glandular pistilado; h. fruto; i. aspecto geral da semente. j - s: P. minutulus Müll. Arg. j. hábito; k. lâmina foliar; l. estípula; m. flor estaminada; $\mathrm{n}$. sépala, face ventral evidenciando a faixa central, flor estaminada; o. flor pistilada; p. sépala, face ventral evidenciando a faixa central, flor pistilada; q. disco glandular pistilado, aspecto; r. fruto; s. semente, aspecto dorsi-ventral. (Escala: $a, j \mathrm{j}=2 \mathrm{~cm} ; \mathrm{b}, \mathrm{e}, \mathrm{h}$, $\mathrm{k}=2 \mathrm{~mm} ; \mathrm{c}, \mathrm{d}, \mathrm{g}, \mathrm{i}, \mathrm{q}, \mathrm{r}, \mathrm{s}=1 \mathrm{~mm} ; \mathrm{f}, \mathrm{m}, \mathrm{n}, \mathrm{o}=0,5 \mathrm{~mm} ; \mathrm{l}=0,25 \mathrm{~mm} ; \mathrm{p}=0,4 \mathrm{~mm}$ ) 
O gênero Phyllanthus L. (Phyllantheae - Euphorbiaceae Juss.) no bioma Caatinga do estado de

Lima.60-3523 (PEUFR); idem, 18/X/84, fl., Rodal 315 (PEUFR); idem, 08/V/95, fl., Gomes, A. P. S. Laurênio, A. \& Tschá 314 (PEUFR); idem, 19/X/94, fl., Travassos 225 (PEUFR); idem, 19/X/94, fl. fr., Lucena 07 (PEUFR); Garanhuns, 26/I/77, fl., I. Pontual. 77 (PEUFR). Material adicional examinado: BRASIL. BAHIA: Miguel Calmon, 13/VII/ 91, Miranda \& Esteves 294 (PEUFR); idem, Lamarão do Passé, 10/VII/94, fl. fr., Guedes 3374 (PEUFR); idem, Rio de Contas, 21/X/ 97, fl. fr., M. Alves et al.. 1336 (PEUFR).

Distribuição exclusiva no Brasil, sendo referida para Bahia, Espírito Santo, Distrito Federal e Pernambuco (Müeller, 1873; Cordeiro, 1992). Ocorre nos campos rupestres da Cadeira do Espinhaço, em Minas Gerais e na Chapada Diamantina, Bahia, e em restingas no litoral da Bahia e do Espírito Santo (Cordeiro, 1992) e no Cerrado no Distrito Federal (Almeida et al., 1998).

$\mathrm{Na}$ área de estudo é encontrada nos municípios de Buíque, Garanhuns e Afrânio; no primeiro, vegeta no complexo CaatingaCampo, formado por uma vegetação perenifólia nos chapadões arenitícos, crescendo em solos arenosos, branco ou violáceos, e ainda entre fendas de rochas; já no segundo, é referido para o morro do Mongano (ca.1.100 m) e em Afrânio, em áreas arenosas.

Phyllanthus klotzschianus foi posicionado por Müeller (1873) em $P$. sect. Xyllophylla (L.) Baill. Posteriormente, Santiago (1988) fundamentando-se nas distinções existentes no padrão de ornamentação da exina dos grãos de pólen das espécies brasileiras e antilhanas, transferiu para $P$. sect. Choretropsis todas as espécies brasileiras do gênero que apresentam cladódios, e propôs para a mesma duas subseções: P. sect. Choretropsis subsect. Choretropsis, caracterizada pelos cladódios subcilíndricos e $P$. sect. Choretropsis subsect. Applanata Santiago, pelos cladódios laminares, na qual está incluído $P$. klotzschianus. Müeller (1873) estabeleceu nove variedades para a espécie, de difícil distinção, baseado na largura e tamanho dos cladódios, as quais não foram aceitas no trabalho aqui apresentado.

P. klotzschianus é reconhecido pelo caule com ramos secundários modificados em cladódios laminares, em cujas margens estão dispostas flores sésseis solitárias ou em címulas unissexuais. Apresenta semelhança vegetativa com $P$. angustissimus Müll. Arg, espécie comum em Minas Gerais, diferindo da mesma pelas suas flores sésseis, tecas assimétricas e ramos dos estiletes eretos, uma vez que em $P$. angustissimus as flores são visivelmente pediceladas, as tecas são simétricas e os ramos dos estiletes são reflexos. Floresce e frutifica em janeiro, abril, setembro e outubro.

Phyllanthus minutulus Müll. Arg. in Mart., Fl. bras. 11 (2): 54.1874.

Fig. $4, \mathrm{j}-\mathrm{s}$

Erva 5-10,5 cm alt., monóica, ereta, anual, glabra. Caule cilíndrico, vináceo. Ramificação filantóide. Ramos decíduos, 1,1-2,1 cm compr., pinatiformes, cilíndricos, verde a vináceos. Estípulas 0,5-0,8 mm compr., lanceoladas, uninérveas, persistentes, escariosas, vináceas. Catafilos ca.0,6 mm compr., lanceolados, acuminados, rígidos, vináceos. Pecíolo 0,3-0,4 mm compr., cilíndrico, vináceo. Lâmina 2,65,1 x 1,4-2 mm compr., subcartácea, oval a oval-elíptica, oval-oblonga, base arredondada, ápice obtuso, apiculado, margem inteira, levemente vinácea, discolor, face adaxial verde-escura, abaxial verde-cinérea, vinácea na porção apical; venação broquidodróma. Címulas unissexuais estaminadas, racemiformes, com 2-3 flores cada, dispostas ao longo dos ramos desde a base até mais da metade do seu comprimento; brácteas estaminadas numerosas, imbricativas, 0,5$0,8 \mathrm{~mm}$ compr., estreitamente triangulares, adensadas, róseas. Flores estaminadas, pedicelo ca.0,4 mm compr., subcilíndrico; sépalas 5, ca.0,3 mm compr., obovais, ápice arredondado, levemente mucronulado, carenadas dorsalmente, nervura central evidente, amareladas; disco glandular 5- 
segmentado; segmentos glandular-estipitados; estames 2, unidos em coluna, anteras sésseis no topo da coluna, rimas horizontais. Flores pistiladas, axilares, solitárias, na porção distal dos ramos; brácteas 0,7-0,8 mm compr., triangulares, hialinas; pedicelo 1-1,1 mm compr., cilíndrico; sépalas 5, com 1,2-1,4 mm compr., obovais, discretamente venadas; disco glandular cupuliforme; ovário ca. $4 \mathrm{~mm}$ compr., depresso-oval; estiletes 3, livres, bífidos, ascendente; estigma levemente bilobado. Cápsula ca. $1 \mathrm{~mm}$ compr. e 1,8mm diâm, oblata, sépalas e estiletes persistentes. Sementes 0,9$1 \mathrm{~mm}$ compr., trígonas com estrias transversais arranjadas em fileiras longitudinais regulares, castanho-escuras.

Material examinado: BRASIL. PERNAMBUCO: Bonito, 01/VIII/01, fl. fr., M. J. Silva 112 113, 114, 115 (PEUFR).

É referida apenas para o Brasil, estando amplamente distribuída desde a região Norte (AM, AP, PA), e Centro-Oeste (GO) até Sudeste e Sul (MG, SC) (Cordeiro, 1992; Almeida et al., 1998) e registrada pela primeira vez na região Nordeste (PE), aqui neste trabalho. Na área de estudo foi encontrada apenas no município de Bonito, na floresta Ombrófila Montana (880 m alt.), conhecida como Mata do Estado. Cresce sobre pequenos afloramentos rochosos, revestidos por mosaicos de musgos, formando grande população.

É caracterizada por ser uma planta de pequeno porte, com indivíduos variando de 5$10,5 \mathrm{~cm}$ de altura, partes vegetativas, em geral, fortemente vináceas, pelas flores estaminadas em címulas racemiformes, dispostas da base até mais da metade do comprimento dos ramos e pelas sementes com estrias transversais dispostas regularmente de forma longitudinal. São ainda caracteres para o seu fácil reconhecimento, as flores com 2 estames unidos e os ramos secundários curtos (1,1-2,1 $\mathrm{cm})$. Difere das demais espécies estudadas pela preferência ambiental e tamanho diminuto de suas estruturas vegetativas e reprodutivas, embora compartilhe com Phyllanthus amarus,
P. niruri, P. tenellus e P. stipulatus o mesmo padrão filantóide de ramificação. É provável que Floresce e frutifica todo ano.

Phyllanthus niruri L., Sp. pl. 2: 981-982. 1753. Fig. 5, a - j

Erva $12-40 \mathrm{~cm}$ alt., ereta, anual, monóica, glabra. Caule cilíndrico, esverdeado, densa a esparsamente ramificado, com fissuras próximas a base. Ramificação filantóide. Ramos decíduos, 3,5-9,5 cm compr., cilíndricos, esverdeados a vináceos; Catafilos 1-1,2 mm compr., linear-lanceolados, acuminados, verde a vináceos, membranáceos a escariosos. Estípulas 1,2-1,9 mm compr., persistentes, linear-lanceoladas a lineares, verde a vináceas. Pecíolo 0,3-0,4 mm compr., cilíndrico, verdeglauco a vináceos. Lâmina 5,0-7,5 x 2,5-3,8 $\mathrm{mm}$, membranácea, oblonga a oblongo-elíptica, base levemente cordada, assimétrica, ápice obtuso a arredondado, margem inteira, levemente vinácea, discolor, face adaxial verdeescura, abaxial verde-glauca. Címulas estaminadas com 2-3 flores dispostas da base até mais da metade dos ramos; brácteas 0,50,6 mm compr., lineares, hialinas. Flores estaminadas, pedicelo 1,9-2,5 mm compr.; sépalas 5, com 1,2-1,4 x 0,8-1 mm compr., obovais, côncavas, nervura central evidente, ápice arredondado; disco glandular 5segmentado, segmentos trapezoidais de margens verruculosas; estames 3, quase totalmente unidos em coluna, anteras com rimas horizontais. Flores pistiladas, solitárias, dispostas na porção distal dos ramos; brácteas 0,7-0,8 mm compr., lineares, hialinas; pedicelo 2,8-3,1 mm compr., anguloso, esverdeado; sépalas 5, com 1,7-2 mm compr., largamente elípticas a obovais, côncavas, venadas, ápice arredondado; disco glandular anular a cupuliforme, margem levemente ondulada, carnoso; ovário 0,4-1 mm compr., oblato a depresso - oval; estiletes 3, livres, bífidos, ascendentes, estigma capitado. Cápsula 1,21,3 mm compr. e ca.2-2,1 mm diâm., oblata, lisa, levemente venulada, sépalas acrescentes e estiletes persistentes. Sementes 1-1,1mm 
O gênero Phyllanthus L. (Phyllantheae - Euphorbiaceae Juss.) no bioma Caatinga do estado de Pernambuco - Brasil

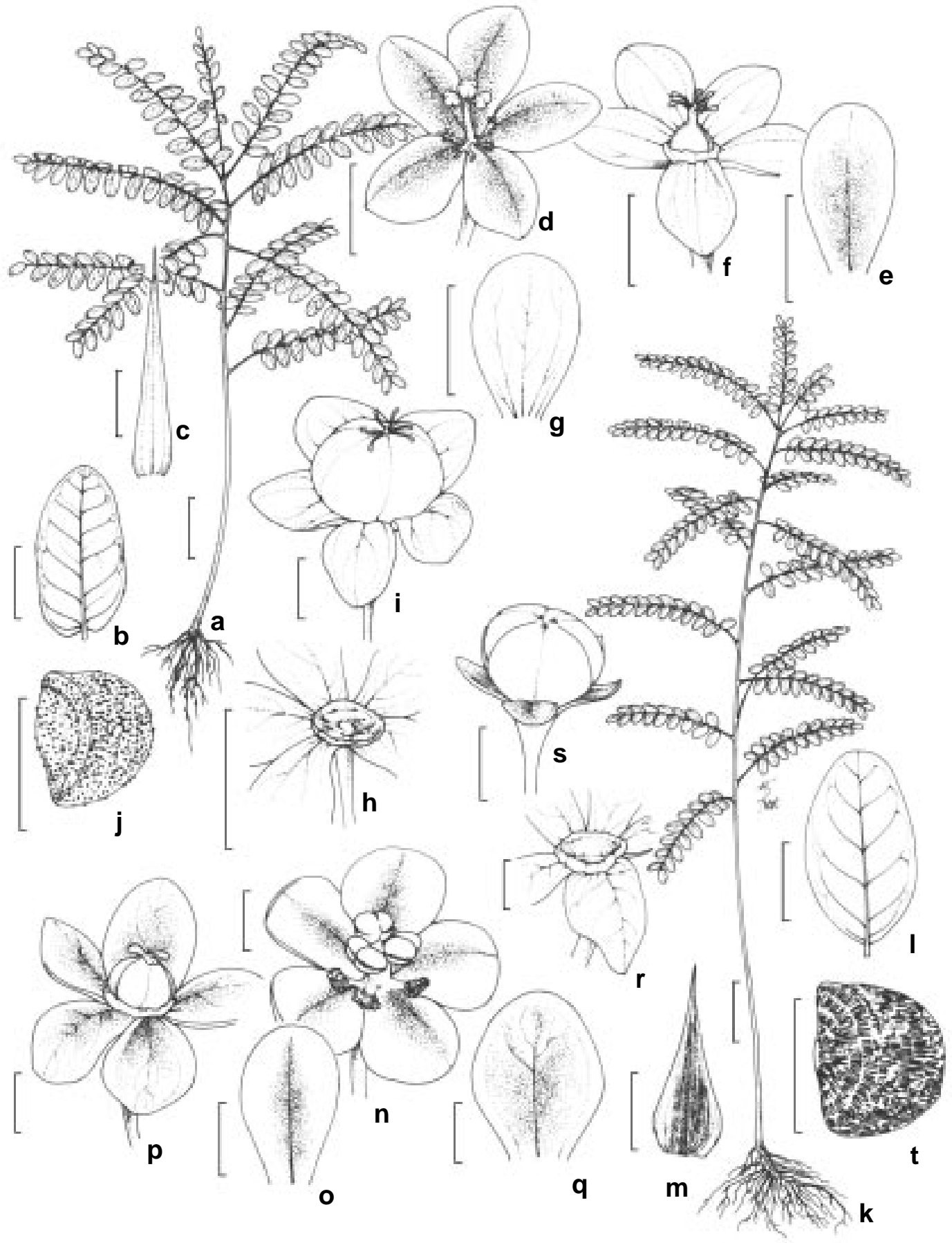

Figura 5: a - j: Phyllanthus niruri L. a. hábito; b. lâmina foliar; c. estípula; d. flor estaminada; e. sépala, face ventral evidenciando a faixa central, flor estaminada; f. flor pistilada; g. sépala, face ventral evidenciando a faixa central, flor pistilada; h. disco glandular pistilado, aspecto; i. fruto; j. semente, aspecto dorsi-ventral; $\mathrm{k}$ - t: P. stipulatus (Raf.) Webster. k. hábito; l. lâmina foliar; m. estípula; n. flor estaminada; o. sépala, face ventral evidenciando a faixa central, flor estaminada; p. flor pistilada; q. sépala, face ventral evidenciando a faixa central, flor pistilada; r. disco glandular pistilado, aspecto; s. fruto; t. semente, face dorsi-ventral. (Escala: $a, k=2 \mathrm{~cm} ; \mathrm{b}, 1, \mathrm{~s}, \mathrm{t}=2 \mathrm{~mm}$; c, m, n, o, p, q, r = 0,5 mm; d, e, f, $\mathrm{g}, \mathrm{h}, \mathrm{i}, \mathrm{j}=1 \mathrm{~mm})$ 
compr., trígonas, densamente verruculosas ao longo de linhas longitudinais, castanho-claras.

Material examinado: BRASIL. PERNAMBUCO: Bonito, 06/III/99, fl. fr., E. A. Santos 07 (PEUFR); idem, 01/VIII/01, fl. fr., Silva, M. J. 109 (PEUFR); Brejo da Madre de Deus, 05/II/99, fl. fr., L. Krause \& A. Liebig 112 (PEUFR); Caruaru, 25/VII/01, fl. fr., Silva, M. J. 103, 104, 106 (PEUFR); idem, 10/IV/02, fl. fr., Silva, M. J. 182, 183, 184 (PEUFR); Limoeiro, 21/IX/01, fl. fr., Silva, M. J. 127 (PEUFR); Ouricuri, 04/V/71, fl., Heringer et al.. 480 (PEUFR); Fernando de Noronha, 03/ VI/1993, fl. fr., Miranda et al. 985 (PEUFR); idem, 02/VI/1993, fl. fr., Miranda et al.. 930 (PEUFR); idem, 01/VI/1983, fl. fr., Miranda et al.. 840 (PEUFR); Recife, 07/VIII/99, fl. fr., Paiva 34 (PEUFR); idem, 26/VIII/02, fl. fr., M. J. Silva 191, 195, 196, 200 (PEUFR); Carnaubeira, 17/V/71 Heringer et. al. 805 (PEUFR); Igarassu, 06/VI/98, fl. fr., Lucena 523 (PEUFR); idem, 16/X/02, fl. fr., Silva, M. J. 241, 242, 244, 245, 246, 247 (PEUFR). Material adicional examinado: BRASIL. ALAGOAS: Piranhas, 07/VI/99, fl., Silva \& Sales 466 (PEUFR, UFP); idem, 27/VI/99, fl., Silva \& Moura 676 (PEUFR, UFP); São José Laje, 26/II/02, fl. fr., M. Oliveira \& A. A. Grilo 766 (UFP). PIAUÍ: Teresina, 31/V/99, fl. fr., Soares Filho 05 (PEUFR); idem, 25/VII/99, fl. fr., Soares Filho 30 (PEUFR).

Distribuição exclusiva nas Américas, desde o Sul do Texas até o Norte da Argentina, incluindo Antilhas (Webster, 1970). No Brasil ocorre nas regiões Nordeste (CE, BA, AL, PI, PE, SE e MA), Sudeste (SP e RJ), Sul (RG e SC) e Centro Oeste (DF), (Cordeiro, 1992; Smith et al.1988; Ulysséa \& Amaral, 1997) em áreas abertas de diferentes tipos vegetacionais como Caatinga, Campo, Cerrado, Restinga e Mata Atlântica. É comum ser encontrada em campos cultivados, clareiras de matas, margens de estradas, terrenos baldios e áreas antropizadas. Em Pernambuco é amplamente distribuída desde as zonas do Litoral e Mata até a das Caatingas, em bordas de mata da floresta Atlântica e da Caatinga. Cresce em locais úmidos e sombreados de áreas cultivadas, pastos e próximo a habitações, em solos arenosos ou areno-argilosos.

Müeller $(1866 ; 1873)$ reconheceu seis variedades para a mesma, das quais Phyllanthus niruri var. genuinus é atualmente um dos sinônimos de P. amarus. Lourteig \& O'Donell (1942) se equivocou ao descrever suas sementes como sendo estriadas transversalmente, característica esta pertencente a $P$. amarus.

É uma das espécies mais complexas do gênero por apresentar freqüentes casos de segregações interpopulacionais, acarretando visíveis variações morfológicas perceptíveis no nível da integridade dos filetes (livres ou unidos), aspecto das glândulas estaminadas e forma das sépalas, conforme Webster (1956) e verificado neste estudo. Apresenta maiores afinidades com Phyllanthus stipulatus (Raf.) Webster, embora tenha sido confundida na literatura com $P$. amarus Schumach. \& Thonn. Porém, distinguise da primeira pelas suas folhas com base assimétrica e cordada, pelos estames quase totalmente unidos e sementes densamente verruculosas, além dos estiletes bífidos, o que torna fácil seu reconhecimento. Já em Phyllanthus stipulatus (Raf.) Webster as folhas têm base simétrica, aguda a obtusa, estames completamente unidos e semente estriadas. Diferencia-se de Phyllanthus amarus por esta ser a única do gênero a apresentar címulas bissexuais compostas por uma flor pistilada e uma estaminada e ainda possuir sépalas de ápice abruptamente agudo. Floresce e frutifica todo ano, é reconhecida popularmente como Quebrapedra (PE, PI, BA, AL, SE, SC, RS, DF e SC) e Chanca - piedra (Peru).

Phyllanthus stipulatus (Raf.) Webster, Contr. Gray. Herb. 176: 53. 1955.

Moeroris stipulata Raf., Sylva Tellur. 91. 1838.

Fig. 5, $\mathrm{k}-\mathrm{t}$

Erva 30-45 cm alt., ereta, anual, monóica, glabra. Caule cilíndrico a subcilíndrico, esparsamente ramificado, verde a verdeavermelhado, com parênquima aerífero na porção basal, em indivíduos de locais alagados. 
O gênero Phyllanthus L. (Phyllantheae - Euphorbiaceae Juss.) no bioma Caatinga do estado de

Pernambuco - Brasil

Ramificação filantóide. Ramos decíduos, 2,67,5 cm compr., pinatiformes, cilíndricos, verde a vináceos. Catafilos 0,9-2,2 $\mathrm{mm}$ compr., largamente triangulares, acuminados, membranáceos a escariosos. Estípulas 0,9-1,2 $\mathrm{mm}$ compr., lanceoladas, persistentes, acuminadas, verde-claro a vináceas, membranáceas. Pecíolo 0,5-0,8 mm compr., cilíndrico. Lâmina 7,2-10,0 x 2,1-4,8 mm compr., membranácea, oblongo-elíptica a oblonga, base aguda a obtusa, ápice arredondado, margem inteira, discolor, face adaxial verde-escura, abaxial verde-glauca a vinácea na porção apical. Címulas unissexuais estaminadas, 3-4 (5) flores na porção proximal dos ramos; brácteas estaminadas 0,3-0,4 mm compr., lineares, hialinas ou róseas. Flores estaminadas, pedicelo 0,8-1,0 mm compr., cilíndrico; sépalas 5, obovais, nervura central evidente, ápice arredondado; disco glandular 5-segmentado, segmentos arredondados, verruculosos; estames 3, totalmente unidos em coluna de 0,6-0,7 mm compr., anteras com rimas horizontais. Flores pistiladas, solitárias, dispostas na porção distal dos ramos; brácteas pistiladas $0,7-0,8 \mathrm{~mm}$ compr., estreitamente triangulares; pedicelo 1,7-1,8 $\mathrm{mm}$ compr., subcilíndrico; sépalas 5, com 1,6-1,8 mm compr., obovais, faixa central elíptica a oboval, discretamente venulada, ápice arredondado; disco glandular cupuliforme, margem levemente lobada, carnoso; ovário 0,6-0,8 mm compr., depresso-oval; estiletes 3 , livres, bífidos, ramos recurvados, ascendentes, estigma subcaptado. Cápsula 1,6-1,8 mm compr e 2-2,1 mm diâm, depresso-oval; cálice acrescente e estiletes persistentes. Sementes 0,9-1,1 mm compr., trígonas, estrias transversais dispostas em fileiras longitudinais regulares, castanho-escuras.

Material examinado: BRASIL. PERNAMBUCO: Caruaru, 05/X/01, fl. fr., M. J. Silva 133, 134, 135, 136, 137, 139, 140 (PEUFR); idem, 10/ IV/02, fl. fr., M. J, Silva 178, 179, 180 (PEUFR). Material adicional: Bonito, 01/VIII/01, fl. fr., M. J. Silva 110111 (PEUFR); Cabo, 17/IX/99, fl. fr., Paiva, Jr. M.
50 (PEUFR); Igarassu, 20/XI/02, fl. fr., M. J. Silva 275, 276, 277, 278, 279 (PEUFR); Maraial, 20/II/94, fl. fr., Miranda \& Félix 1620 (PEUFR); Recife, 22/VIII/02, fl. fr., M. J. Silva 210, 211, 212, 213, 214, 217 (PEUFR); São Benedito do Sul, 23/XI/02, fl. fr., M. J. Silva 280, 281, 282, 283, 284, 285 (PEUFR).

Distribuição desde o sudeste dos Estados Unidos, incluindo Antilhas, até sudeste do Brasil, em áreas alagadas, brejosas, com solos, em geral, hidromórficos. No Brasil é referida para Minas Gerais, Pernambuco, Rio Grande do Sul e Santa Catarina (Ulysséa \& Amaral, 1993, Smith et al. 1988). Na área de estudo foi registrada apenas para as florestas Montanas dos municípios de Bonito (Mata do estado) e Caruaru (Serra dos Cavalos), crescendo em áreas agricultáveis, em solos hidromórficos.

Apresenta maiores afinidades com Phyllanthus niruri, embora seja facilmente confundida com $P$. amarus conforme discutido nos comentários dessas duas espécies. Floresce e frutifica em todo ano. Em Pernambuco e Minas Gerais é conhecida popularmente como quebra-pedra e erva de pombinha, respectivamente.

Phyllanthus tenellus Roxb., Flora Indica ed. 2. 3: 668. 1882.

Fig. 6, a-j

Erva $15-30 \mathrm{~cm}$ alt., monóica, glabra. Caule principal cilíndrico a subcilíndrico, fortemente vináceo, esparso a densamente ramificado ou não ramificado. Ramificação filantóide. Ramos decíduos 4,5-8,5 cm compr., pinatiformes, subcilíndricos, verde-vináceos. Catafilos 0,9-1 $\mathrm{mm}$ compr., lanceolados, acuminados, escariosos e fortemente vináceos. Estípulas 1,11,2 mm compr., lanceoladas, persistentes, acuminadas, vináceas. Pecíolo ca. $1 \mathrm{~mm}$ compr., subcilíndrico, discretamente vináceo. Lâmina 7-15 x 5-11 mm compr., membranácea, elíptica a elíptico-oboval, base aguda a obtusa, ápice obtuso, margem inteira, levemente vinácea, discolor, face adaxial verde-escura, abaxial verde-glauca. Címulas proximais bissexuais, com 1-2 flores estaminadas e 1-2 


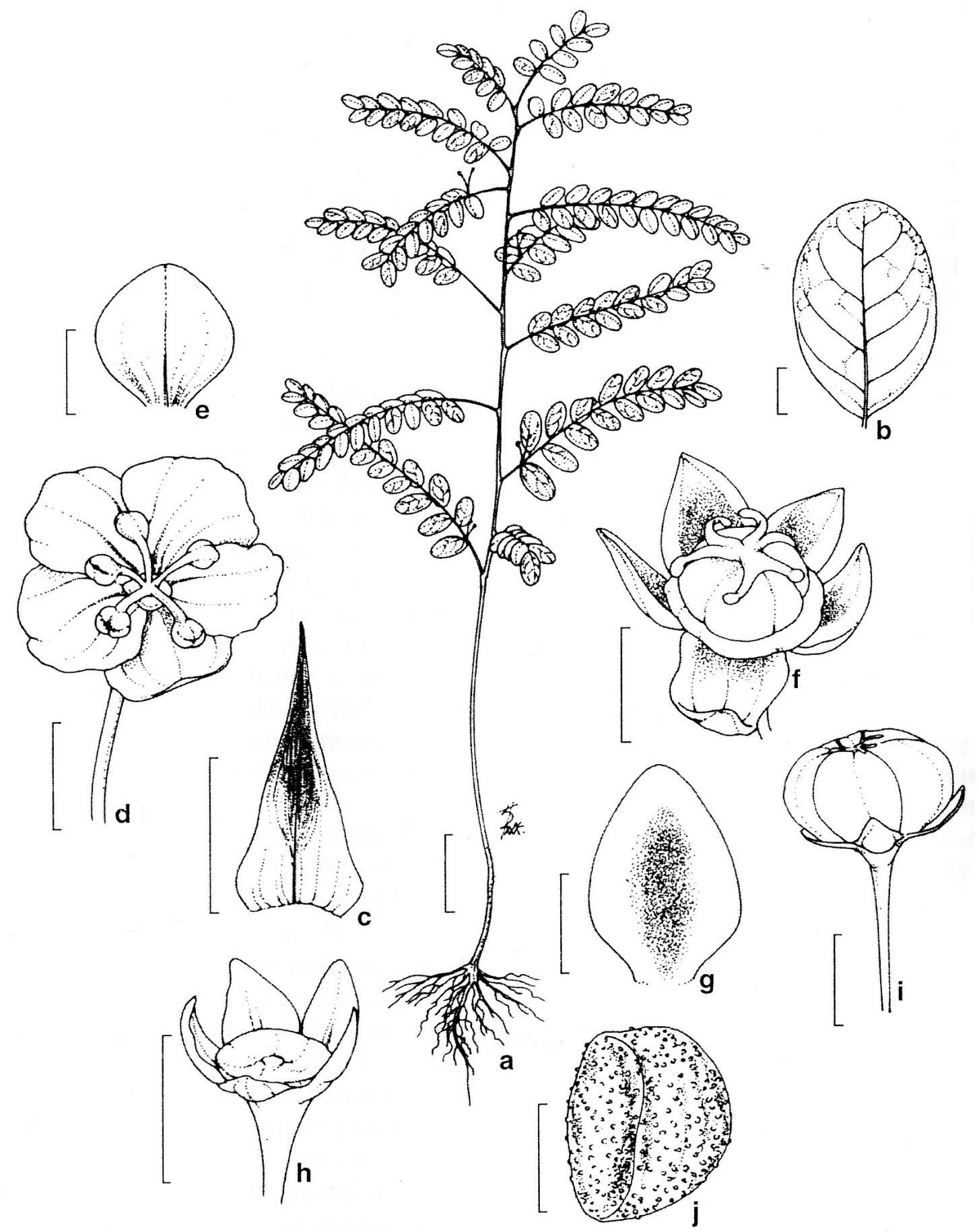

Figura 6: a-j: Phyllanthus tenellus Roxb. a. hábito; b. lâmina foliar; c. estípula; d. flor estaminada; e. sépala, face ventral evidenciando a faixa central, flor estaminada; f. flor pistilada; g. sépala, face ventral evidenciando a faixa central, flor pistilada; h. disco glandular pistilado; i. fruto; j. semente, aspecto dorsi-ventral. (Esacala: $a=2 \mathrm{~cm} ; \mathrm{b}=2 \mathrm{~mm}$; $\mathrm{c}, \mathrm{d}$, e, f, $g, j=0,5 \mathrm{~mm} ; \mathrm{h}, \mathrm{i}=1 \mathrm{~mm}$ ) 
O gênero Phyllanthus L. (Phyllantheae - Euphorbiaceae Juss.) no bioma Caatinga do estado de

flores pistiladas; címulas distais unicamente pistiladas, reduzidas a uma única flor; brácteas 0,4-0,6 mm compr., triangulares, hialinas. Flores estaminadas, pedicelo 1-1,2 mm compr., cilíndrico; sépalas 5, com 0,6-0,7mm compr., elíptico-obovais, nervura central evidente, ápice arredondado; disco glandular 5-segmentado, segmentos obtriangulares; estames 5, livres, encurvados, anteras com rimas subhorizontais. Flores pistiladas, pedicelo $(2,3)$ 4,0-6,5 mm compr., flexuoso, filiforme com base pulviniforme, vináceo; sépalas 5 , com $0,7-0,9$ x 0,3-0,4 mm compr., ovais, faixa central elíptica, ápice agudo; disco glandular pateliforme; ovário ca.0,4 $\mathrm{mm}$ compr., depresso-oval; estiletes 3, livres, bífidos, retrorsos; estigma subcapitado. Cápsula 1-1,1 mm compr., e 1,9-2 mm de diâm., oblata, esverdeada, cálice e estiletes persistentes, pedicelo filiforme. Sementes trígonas, ca. $1 \mathrm{~mm}$ compr., minutamente verruculosas dispostas irregularmente, castanho-claras.

Material examinado: BRASIL. PERNAMBUCO: Buíque, 11/II/95, fl. fr., Silva et al. 749 (PEUFR); Caruaru, 05/X/01, fr., M. J. Silva 138 (PEUFR); idem, 06/I/02, fl. fr., M. J. Silva 160, 161, 162, 163 (PEUFR); Petrolina, 07/IX/02, fl. fr., M. J. Silva 231, 232, 233 (PEUFR): Material Adicional: BRASIL.SÃO PAULO: Moji da Cruzes, 16/ I/41, fl. fr., B. Pickel 9712 (IPA).

Distribuição ampla nas regiões tropicais e subtropicais do mundo (África, Ásia, Austrália, Américas). Nas Américas ocorre desde os Estados Unidos até a Argentina, incluindo Antilhas (Webster 1956, 1970; Correl \& Correl, 1982; Adams, 1972; Müeller, 1873). No Brasil está amplamente distribuída no Distrito Federal, Pernambuco, Rio Grande do Sul, Rio de Janeiro, São Paulo e Santa Catarina (Müeller, 1873; Smith et al.1988; Cordeiro, 1981; Allem 1977.) $\mathrm{Na}$ área de estudo foi encontrada como invasora em áreas cultivadas, terrenos baldios, canteiros de jardins e margens de calçadas em locais úmidos. Esta espécie é facilmente reconhecida pelas flores pistiladas com pedicelo longo $(4-6,5 \mathrm{~mm})$, filiforme e flexuoso, visivelmente articulado, com base pulviniforme, dispostas em címulas unifloras na porção distal dos ramos, bem como pelo androceu constituído por cinco estames livres. Floresce e frutifica de dezembro a janeiro. Em Pernambuco é conhecida popularmente como quebra-pedra roxo.

\section{CONCLUSÕES}

A maioria das espécies estudadas apresenta distribuição na zona das Caatingas do Estado de Pernambuco, sendo que Phyllanthus claussenii Müll. Arg., P. heteradenius Müll. Arg., P. jacobinensis Müll. Arg. e P. klotzschianus Müll. Arg. são exclusivas dessa zona, ocorrendo em vegetação de Caatinga em municípios das subzonas do Agreste e Sertão (Andrade-Lima, 1960). Nesses ambientes, são encontradas preferencialmente em sombras de arbustos ou de árvores e, às vezes, em afloramentos rochosos. Já Phyllanthus acuminatus Vahl, P. minutulus Müll. Arg. e P. stipulatus (Raf.) Webster apresentam distribuição na Zona das Caatingas, porém em áreas mais úmidas e elevadas (800 a 1000m), com vegetação de floresta semi-decídua ou perenifólia (florestas Montanas, Sales et al. 1998) como também nas zonas da Mata e Litoral, na floresta Atlântica. As demais espécies mostram-se amplamente distribuídas, ocorrendo desde a zona do Litoral e Mata até a subzona do Sertão, habitando áreas abertas e antropizadas de diferentes tipos vegetacionais ou como invasoras em áreas agricultáveis e ou ruderais.

\section{AGRADECIMENTOS}

Agradecemos aqueles que de alguma forma contribuíram para a realização deste trabalho e ao CNPq pela concessão da bolsa de estudo.

\section{REFERÊNCIAS BIBLIOGRÁFICAS}

Adams, C. D. 1972. Flowering Plants of Jamaic. University of West Indies. p. 430-431. 
Airy Shaw, H. K. 1971. The Euphorbiaceae of Siam. Kew Bulletin 26: 312 - 326.

Allem, A. C. 1977. Notas taxonômicas sobre as tribos Phyllantheae, Dalechampieae e Manihotieae (Euphorbiaceae Juss.) no Rio Grande do Sul, Iheringia 22: 3-5.

Almeida, S. P.; Proença, C. E. B.; Sano, S. M. \& Ribeiro, J.F. 1998. Cerrado: Espécies vegetais úteis. Planaltina (DF): Embrapa. $464 \mathrm{p}$.

Andrade-Lima, D. 1960. Estudos Fitogeográficos de Pernambuco. $2^{\text {a }}$ ed. Revista do Arquivo do Instituto de Pesquisas Agronômicas 5: 305-341.

Bentham, G. 1880. Euphorbiaceae. In: Genera Plantarum. (G. Bentham \& J. D. Hooker, eds.) v. 3, London. 459 pp.

Baillon, H. 1958. Étude Génerale du Groupe des Euphorbiaceés. 684 pp.Victor Masson, Paris.

. 1860. Monographie des Phyllanthus. Primiére parte. Adansonia 1: 23 - 43.

Brummitt, R. F. \& Powell, C. E. 1992. Authors of Plants Names. Londres: Royal Botanic Gardens, Kew. 732p.

Cordeiro, I. Euphorbiaceae In: Flora Fanerogâmica do Parque Estadual das Fontes do Ipiranga. Hoehnea 9: 22-23. 1992. Flora da Serra do Cipó, MG: Euphorbiaceae. Boletim de Botânica da Universidade de São Paulo 13: 169 217.

. 1995. Euphorbiaceae. In: Stannard, B. L. Flora of the Pico das Almas, Chapada Diamantina, Bahia - Brasil. Royal Botanic Garden, Kew. p.300-317.

Croizat, L. 1943. New or critica Euphorbiaceae of Brazil. Tropical Woods 76: 11-14.

1944. Three new Amazonian species of Phyllanthus L. Tropical Woods 78: 5 -9.

Correll, D. \& Correl, H. B. 1882. Euphorbiaceae. In: Flora of Bahamas
Archipelago (including the Turks and Caicos Islands) In: Der A. R. Gantner Verlag Kommandit Gesellschaft. p. 834840.

Filho, F. S. Santos, 2000. A família Euphorbiaceae Juss. no Parque Estadual Zoobotânico na cidade de Teresina, Piauí - Brasil. 104p. Dissertação de Mestrado. Universidade Federal Rural de Pernambuco, Recife.

Gille spie, L. J. 1993. Euphorbiaceae of the Guianas: Annotated species checklist and key to the genera. Brittonia 45 (1): 5694.

Grisebach, A. H. R. 1859. Flora of the British West Indian Island. v. 16 789p.

1860. Plantae Wrightianae e Cuba Orietali. I. Mem. Amer. Acad. Ns. 8:153-192.

Hickey, L. J. 1973. Classification of the architecture of dicotiledonous leaves. American Journal of the Linnean Society 60: 17-33.

Hunter, J. T. \& Bruhl, J. J. 1997a. Two new species of Phyllanthus and notes on Phyllanthus and Sauropus (Euphorbiaceae: Phyllantheae) in New South Wales. Telopea 7(2):149-165.

1997b. Three new species of Phyllanthus (Euphorbiaceae: Phyllantheae) for the nothern Territory on the other Phyllanthus species occurring in these regions. Nuytsia 11(2): 147-163.

Hunziker, A. T. 1967. Contribución al Conocimiento de las espécies Argentinas de Phyllanthus Kurtziana 4: 19-27.

Köeppen, W. 1948. Climatologia: Cón un estudio de los climas de la tierra. México: Fondo de Cultura económica 478p.

Lawrence, G. H .M. 1951. Taxonomia das Plantas Vasculares. Lisboa: Fundação Caulouste Gulbenkiar.v. 2, p.767-809.

Linnaeus, C. 1737. Genera Plantarum (1 ${ }^{\mathrm{a}}$ edição). $384 \mathrm{Pp}$. Conrad Wishoff, Leyden.

Rodriguésia 55 (84): 101-126. 2004 
O gênero Phyllanthus L. (Phyllantheae - Euphorbiaceae Juss.) no bioma Caatinga do estado de

1753. Species Plantarum. Londres, Ray Society, v. 1 facsimile, Pp. 1007.

Lourteig, A. \& O'Donell, C. A. 1942. Euphorbiaceae Argentinae-Phyllantheae, Dalechampieae, Cluytieae e Manihotieae. Lilloa 9: 77-173.

Macbride, J. F. 1951. Euphorbiaceae In: Flora of Peru. Field Museum of Natural History 13 (1): 1-200.

Müeller, J. A. 1866. Phyllanthus. In: De Candolle. Prodromus systematis naturalis regni vegetabilis 15 (2): 274456. Victor Masson, Paris.

1873. Euphorbiaceae In: Martius, C. F. von, Eichler, A. W. \& Urban, I. (eds). Flora Brasiliensis. München, Wien, Leipzig, vol. 11 (2): 23-76.

Pax, F. \& Hoffmann, K. 1986. Euphorbiaceae. In: Die Naturl. Planzenfam. (Zweite Aufl.) 19c: 11-233, figs. 6-123.

Radcliffe-Smith, A. 1983. Notes on Euphorbiaceae:XII. Kew Bulletim 36 (2):421-428.

Radford, A. E.; Dickson, W. C.; Massey, J.R. et al. 1974. Vascular plant systematics. New York: Happer \& Row. 891p.

Robinson, C. B. 1909. Philippine. Phyllanthinae. Philipp. Journal of Society Botanic 4: 71-105.

Rossignol, L.; Rossignol, M. \& Haicour, R. 1986. A systematic revision of Phyllanthus subsection Urinaria (Euphorbiaceae). America Journal of Botany 74 (12): 1853-1862.

Sales, M. F. de, Mayo, S. J. \& Rodal, M. J. N. 1998. Plantas Vasculares das florestas Serranas de Pernambuco. Eds. Univ. Fed. Rural de Pernambuco, Royal Botanic Gardens - Kew, CNPq., 130pp.

Sampaio, E. V. S. B. 1996. Fitossociologia. In: Sampaio, E. V. S. B.; Mayo, S. J.; Barbos, M. R. V. (Eds.). Pesquisa Botânica Nordestina: Progresso e
Pespectiva. Recife: Sociedade Botânica do Brasil. p. 203-224.

Santiago, L. J. M. 1988. Estudos preliminares da seção Choretropsis Mull. Ar. Phyllanthus L. (Euphorbiaceae). Bradea 5 (2): 44-48.

Small, J. K. 1933. Manual of Southeastern Flora. New York. p.774-805

Smith, L. B. \& Downs, R. J. 1959. Resumos preliminares das Euphorbiáceas de Santa Catarina. Sellowia 11: 155-231.

Smith, L. B., R. J. Downs \& R. M. Klein. 1988. Euphorbiaceae. In: Reitz, R. (ed.). Flora Ilustrada Catarinense. Itajaí, Santa Catarina.p.1-108.

Standley, P. C. 1926. Trees and Shrubs of Mexico. Contributions from The United States National Herbarium. 23: 594-653. . 1937. Flora of Costa Rica. Field Museum of Natural History $18(1,2)$ : 598-622.

\& Steyermark, J. A. 1949. Flora of Guatemala. Fieldiana Botany 24(6): 25171.

Ulysséa, M. \& Amaral, L. G. 1993. Considerações sobre a identificação de espécies de Phyllanthus (Quebrapedra). Insula 22: 21-38.

1997. Contribuição ao estudo do gênero Phyllanthus (Euphorbiaceae) ocorrente na ilha de Santa Catarina, Brasil. Insula 26: 1-28.

Webster, G. L. 1956. Studies of the Euphorbiaceae, Phyllanthoideae. II. American species or the Phyllanthus described by Linnaeus. Journal of the Arnold Arboretum 37: 1-14.

. 1956-1958. A monographic Study of the West Indian species of the Phyllanthus. Journal of the Arnold Arbor. 37 (1956): 91-122, 217-256, 340359;38 (1957): 51-79, 170-198, 295-375; 39 (1958): 49-100, 111-212. 
\& Burch, D. 1967. Euphorbiaceae In:

Flora do Panamá. Annals the Missouri

Botanical Garden 54: 211-350.

1967. The genera of Euphorbiaceae in the Southeastern the United States. Journal of the Arnold Arboretum 48(3): 332-339.

. 1970. Revision of the Phyllanthus (Euphorbiaceae) in the continental United States. Brittonia 22: 44 -76.

1986. A revision of Phyllanthus (Euphorbiaceae) in Eastern Melanesia. Pacific Science 40 (1-4): 88-105. 1994b. Synopsis of taxa of Euphorbiaceae. Annals of the Missouri Botanical Garden 81 (1): 33 - 144.

2002. A synopsis of the Brazilian taxa of Phyllanthus section Phyllanthus (Euphorbiaceae): Lundellia 5: 1-56.

Zoku, O. J. 1965. Euphorbiaceae. In: Flora of Japan. Washington: Smithsonian Institution. p. 588-589. 